\title{
DUURZAME ONTWIKKELING
}

\section{BESTUURLIJKE VOORWAARDEN VOOR EEN}


De Wetenschappelijke Raad voor het Regeringsbeleid werd in voorlopige vorm ingesteld in 1972. Bij wet van 30 juni 1976 (Stb.413) is de positie van de raad definitief geregeld. De huidige zittingsperiode loopt tot 31 december 2002.

Ingevolge de wet heeft de raad tot taak ten behoeve van het regeringsbeleid wetenschappelijke informatie te verschaffen over ontwikkelingen die op langere termijn de samenleving kunnen beïnvloeden. De raad wordt geacht daarbij tijdig te wijzen op tegenstrijdigheden en te verwachten knelpunten en zich te richten op het formuleren van probleemstellingen ten aanzien van de grote beleidsvraagstukken, alsmede op het aangeven van beleidsalternatieven.

Volgens de wet stelt de WRR zijn eigen werkprogramma vast, na overleg met de minister-president die hiertoe de Raad van Ministers hoort.

De samenstelling van de raad is:

prof.mr. M. Scheltema (voorzitter)

prof.dr.ir. J. Bouma

prof.dr. F.A.G. den Butter

prof.dr. M.C.E. van Dam-Mieras

prof.dr. G.A. van der Knaap

prof.dr. P.L. Meurs

prof.dr. J.L.M. Pelkmans

prof.dr.mr. C.J.M. Schuyt

Secretaris: prof. dr. J. van Sinderen

De WRR is gevestigd:

Plein 1813, nr. 2-4

Postbus 20004

2500 EA 's-Gravenhage

Telefoon 070-356 46 oo

Telefax 070-356 4685

E-mailinfo@wrr.nl

Website http://www.wrr.nl 



\section{WRR}

WETENSCHAPPELIJKE RAAD VOOR HET REGERINGSBELEID

\section{DUURZAME ONTWIKKELING}

BESTUURLIJKE VOORWAARDEN VOOR

EEN MOBILISEREND BELEID 
ISBN 90-12-09676-6 


\section{$w R R$}

Aan de Minister-president Minister van Algemene Zaken

De heer W. Kok

Postbus 20001

2500 EA Den Haag

ons kenmerk

$2602094 / \mathrm{MS} / \mathrm{s}$

\section{Onderwerp}

Rapport n. 62

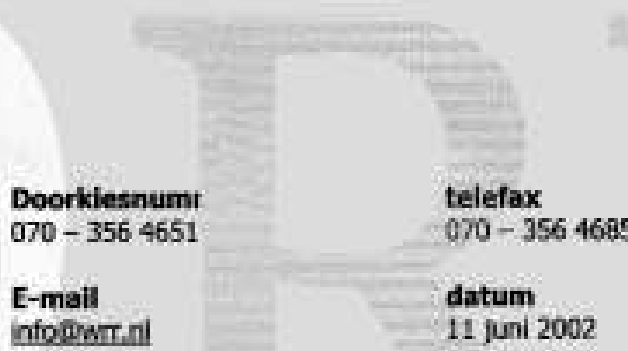

Hierby zenden wij u het rapport ' Duurzame ontwikkeling: bestuurlijke voorwasarden voor een mobiliserend beleid', dat de ultwerking bevat van de adviesaanvraag van de minister van VROM van 23 apni 2002 naar aanleiding van de Nationale Strategie voor Durzame Ontwikkeling. Verkenning wan hot Rojksoverheidsbeleid (2002).

Uitgangspunt voor de bestuurlijke vormgeving van het beleld is de vraag waar het by de invulfing van het begrip duurzaamheid nu precies over gaat. Volgens de raad verdient het aanbeveling om hierbij de ecologische invalshoek voorop te stellen en van daanit de afweging met de economische en sociaal-culturek aspecten te maken. Een alormvattende doeistelling 'duurzame ontwikkeling' zoals in de Nationale Strategle als uitgangspunt is genomen, is voor de ontwikkeling van beleid niet gewenst.

Beworderen van een duurzame cntwikkeling is geen exclusieve overheidsverantwoordelijkheid. Er moet dan ook ruimte worden gegeven aan de eigen verantwoordelijkheid van private actoren. Vereenvoudiging en ontvlechting van het beleid is hierbij de aangewezen weg. De gedachte van één coördinerende minister voor een ruim gedefinieerd begrip duurzame ontwikkeling wijst de raad af; steeds moeten de beleidsproblemen als uitgangspunt worden genomen voor de aanpak van specifieke problemen. Met betrekking tot de internationale samenwerking om de aanpak van de wereldwjide milieuproblemen in gang te zetten, ziet de raad ook mogelijkheden voor vormen van open cobrdinatie, in combinatie met andere bestusurlijke mechanismen, om concrete resultaten te bevorderen.

Volgens de procedure van de Instellingswet WRR ziet de raad graag de bevindingen van de ministerraad tegemcet.
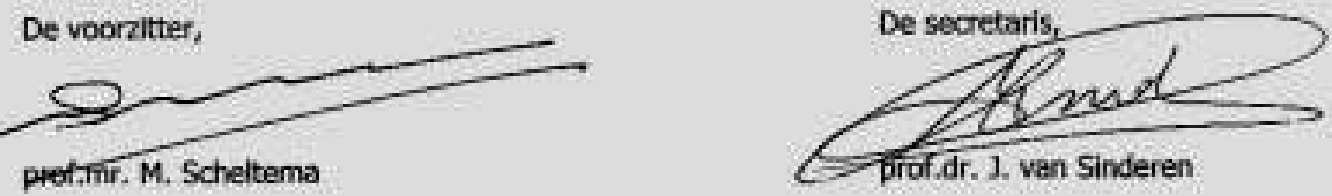


\section{INHOUDSOPGAVE}

$\begin{array}{ll}\text { Ten geleide } & 7\end{array}$

$1 \quad$ Inleiding 9

1.1 De adviesaanvraag 9

1.2 De Verkenning 10

1.3 Opbouw rapport 12

2 Duurzame ontwikkeling: tussen waarde en metabegrip 13

$\begin{array}{ll}2.1 & \text { Groeiende populariteit } \\ & 13\end{array}$

$\begin{array}{lll}2.2 & \text { Duurzame ontwikkeling als waarde } & 14\end{array}$

2.3 Duurzame ontwikkeling als metabegrip $\quad 15$

2.4 Duurzame ontwikkeling in de Verkenning 16

$3 \quad$ Wetenschap en politiek 21

3.1 Grenzen: objectief of subjectief? 21

3.2 De beleidsvoorbereiding: multidimensionaliteit en afweging 25

$4 \quad$ Bestuurlijk-institutionele ontwikkelingen en randvoorwaarden 29

4.1 Beperkingen aan het handelingsvermogen van de overheid 29

4.2 Bestuurlijke vernieuwing en institutionele innovatie
in een multi-actorsamenleving

$5 \quad$ Verdere versterking van bestuurlijke vernieuwing 37

5.1 Samenwerking met actoren in de maatschappij 37

5.1.1 De omgang met burgers en bedrijven $\quad 37$

5.1.2 De omgang met milieu- en intermediaire organisaties 40

5.1.3 Overheid als actor én regisseur $\quad 42$

5.1.4 Het belang van informatie, voorlichting en beleidsanalyse 43

$\begin{array}{lll}5.1 .5 & \text { Indicatoren } & 44\end{array}$

$\begin{array}{lll}5.2 & \text { Bevorderen van samenhang op nationaal niveau } & 47\end{array}$

$\begin{array}{ll}5.3 & \text { Internationale bewerktuiging }\end{array}$

6 Samenvatting en conclusie $\quad 55$

$\begin{array}{lr}\text { Literatuur } & 59\end{array}$ 


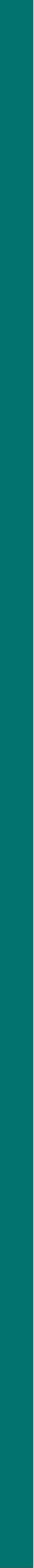




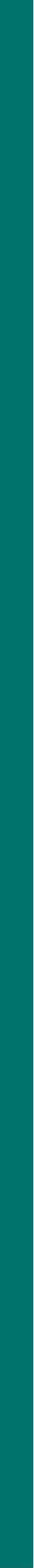




\section{TEN GELEIDE}

Op 23 april 2002 verzocht de regering de WRR een advies uit te brengen over bestuurlijke vernieuwing in het kader van duurzame ontwikkeling.

Het rapport is door de raad voorbereid door een interne projectgroep van de WRR.

Voorzitter was prof.dr.ir. J. Bouma, lid van de raad.

Verder maakten de volgende raads- en stafleden deel uit van de projectgroep:

dr. C. A. Hazeu (tevens projectcoördinator), dr. A.C. Hemerijck,

drs. I.J. Schoonenboom en prof.mr. M. Scheltema (voorzitter van de WRR). 


\subsection{DE ADVIESAANVRAAG}

Het was de verdienste van de World Commission on Environment and Development (commissie-Brundtland) dat zij met haar rapport Our Common Future (1987) de wereldgemeenschap ertoe heeft aangezet om duurzame ontwikkeling als ambitie na te streven. Haar oproep hiertoe heeft een proces van bewustwording rond milieu- en duurzaamheidsvraagstukken gestimuleerd dat na het rapport van Club van Rome van vijftien jaar eerder was ingezakt. Sindsdien is het gebruik van het begrip duurzaamheid gemeengoed geworden en heeft het zich blijvend een plaats verworven als één van de termen waarmee handelen en oogmerken van overheden, bedrijven en maatschappelijke organisaties worden gerechtvaardigd.

Vijf jaar na de Conferentie van de Verenigde Naties over Milieu en Ontwikkeling in Rio de Janeiro (1992), die de Agenda 21 als uitkomst had, is besloten dat nationale overheden een nationale strategie voor duurzame ontwikkeling zullen opstellen, waarin zij verantwoorden wat zij op dit gebied hebben gedaan en wat hun voornemens zijn. Op de vN-conferentie over duurzame ontwikkeling in Johannesburg (eind augustus 2002) zal de balans hiervan worden opgemaakt. De Nederlandse regering heeft ter voorbereiding van de conferentie van Johannesburg de Nationale Strategie voor Duurzame Ontwikkeling. Verkenning van het Rijksoverheidsbeleid (2002) opgesteld - in het vervolg 'de Verkenning' genoemd. Hiernaast is ook een 'maatschappelijke verkenning' verricht van de initiatieven die maatschappelijke actoren ten aanzien van duurzaamheid ondernemen en van de ideeën die daaromtrent bij hen leven. Het is de bedoeling dat deze verkenning aandacht geeft aan dezelfde kernelementen van duurzaamheid als in de Verkenning van het Rijksoverheidsbeleid, namelijk de samenhang tussen economische, sociaal-culturele en ecologische aspecten, de relaties met de armere delen van de wereld en de relatie tussen huidig handelen en de belangen van volgende generaties. De resultaten hiervan zullen eveneens aan de Verenigde Naties ter hand worden gesteld.

In de Verkenning kondigde de regering aan de Wetenschappelijke Raad voor het Regeringsbeleid (WRR) om advies te vragen over het vraagstuk van de bestuurlijke vernieuwing in relatie tot duurzame ontwikkeling. Dit mondde uit in de adviesaanvraag van 23 april 2002 (zie box). In deze adviesaanvraag worden drie aspecten onderscheiden in het vraagstuk hoe de vormgeving van en werkwijze bij beleids- en besluitvorming in het kader van duurzame ontwikkeling zou moeten worden vernieuwd, te weten: internationale samenwerking, het bevorderen van samenhang op nationaal niveau, en samenwerking met actoren in de maatschappij. 
In het hierna volgende rapport gaat de WRR in op de door de regering gestelde vraag en biedt hij een aantal beschouwingen die hij van belang acht in het kader van deze adviesaanvraag.

\section{Tekst van de adviesaanvraag duurzame ontwikkeling van 23 april 2002}

Op 21 december 2001 heeft het Kabinet de Verkenning Rijksoverheidsbeleid naar een Nationale Strategie voor Duurzame Ontwikkeling vastgesteld. In de maanden februari en maart van dit jaar wordt tevens een gerichte maatschappelijke verkenning uitgevoerd. Het is de bedoeling dat de twee verkenningen als bouwstenen kunnen fungeren voor het komende Kabinet, als opmaat naar een nationale strategie. Namens het Kabinet verzoek ik de Wetenschappelijke Raad voor het Regeringsbeleid een rapport op te stellen, waarin op hoofdlijnen een analyse wordt gegeven van een aantal aspecten van de Verkenning Rijksoverheid naar een Nationale Strategie voor Duurzame Ontwikkeling.

In hoofdstuk 8, 'De agenda op de korte termijn', van de verkenning wordt o.a. gesteld, dat De Wetenschappelijke Raad voor het Regeringsbeleid wordt gevraagd zich te buigen over het vraagstuk van de bestuurlijke vernieuwing in relatie tot duurzame ontwikkeling. In hoofdstuk 7, 'Naar een strategie', wordt aangegeven, hoe het Kabinet meent inhoud aan deze bestuurlijke vernieuwing te kunnen geven, met een onderverdeling naar internationale samenwerking, het bevorderen van samenhang en samenwerking met actoren in de maatschappij.

Ik verzoek Uw Raad een rapport op te stellen dat vooral op de beide punten ingaat.

Ik zou het op prijs stellen het rapport, in de vorm van een korte termijn advies, begin mei van dit jaar te ontvangen, zodat het tezamen met het verslag van de Maatschappelijke Verkenning aan het parlement kan worden gezonden.

\subsection{DE VERKENNING}

In de Verkenning formuleert de regering vier uitgangspunten voor de strategievorming ten aanzien van duurzaamheid, te weten:

1 internationale samenwerking;

2 samenhang, door integrale afweging tussen economische, sociaal-culturele en ecologische aspecten;

3 langetermijndenken met behulp van streefbeelden en indicatoren; en

4 samenwerking tussen de verschillende actoren (overheden, bedrijfsleven, wetenschappelijke onderzoekers en burgers).

Deze uitgangspunten worden in verband gebracht met een vijftal thema's die voor Nederland van groot belang zijn, te weten: bevolking, klimaat, water, biodiversiteit, en kennis. De systematiek die met het oog op duurzaamheid wordt bepleit, houdt in dat bij ieder van deze thema's geprobeerd wordt de relaties zichtbaar te maken en de samenhang tussen doelstellingen te vergroten binnen en tussen de economische, sociaal-culturele en ecologische aspecten. 
De Verkenning formuleert het als volgt:

Bij duurzame ontwikkeling gaat het dus om de samenhang tussen economische, sociaal-culturele en ecologische aspecten ter voorkoming van ongewenste effecten en om het integreren van het beleid voor al die aspecten. Wanneer de nadruk te veel ligt op één van deze aspecten, zonder te letten op de gevolgen voor andere aspecten, is dat op den duur nadelig voor alle aspecten. We zoeken een meerwaarde door deze aspecten telkens in samenhang te bezien. Dat betekent dat bij elke besluitvorming een afweging dient plaats te vinden, waarbij al deze aspecten een rol spelen. (Verkenning: 8)

In dit kader zal, via de verder te ontwikkelen nieuwe begrotingssystematiek, ook de samenhang zichtbaar worden gemaakt tussen doelstellingen en uitgaven die relevant zijn met het oog op duurzaamheid. Ook zal een duurzameontwikkelingsbeoordeling worden voorbereid voor relevante investeringen en nieuwe beleidsinitiatieven van de rijksoverheid. Hiernaast zullen voor elk bestuurlijk niveau en voor elke set van thema's indicatoren worden ontwikkeld om de voortgang bij duurzame ontwikkeling te meten.

De Verkenning pleit er dan ook voor dat de samenhangen zichtbaar worden gemaakt voor het hier en nu, maar ook tussen de Nederlandse activiteiten en beleidsarrangementen en de situatie elders in de wereld, en tussen nu en later. Zowel internationale samenwerking als langetermijndenken maken dan ook onlosmakelijk deel uit van een duurzaamheidsstrategie. Nationaal en internationaal beleid dienen consistent te zijn gericht op duurzaamheid, maar ook de samenwerking tussen centrale overheid, lagere overheden en semi-publieke organen en tussen de overheid en private actoren dient met het oog op duurzaamheid te worden bevorderd, opdat ook hiertussen de samenhang kan worden vergroot.

De Verkenning laat voorts zien wat de ontwikkelingen en de beleidsdoelstellingen zijn op de vijf genoemde thema's. Zij plaatst deze in de Europese en wijdere internationale context, wijst de tekortkomingen aan vanuit het gezichtspunt van samenhang tussen economische, sociaal-culturele en ecologische aspecten, en formuleert streefbeelden en doelstellingen voor de langere termijn. Om de vorderingen ten aanzien van duurzame ontwikkelingen nationaal en internationaal zichtbaar en beoordeelbaar te maken, wordt in bijlage 2 van de Verkenning een eerste proeve van indicatoren voor de economische, sociaalculturele en ecologische aspecten gepresenteerd.

Met haar benadering van duurzame ontwikkeling sluit de regering aan bij een bredere internationale tendens. Zo besloot de Europese Raad in Barcelona in maart 2002, in vervolg op de in Göteborg (2001) gemaakte afspraken, tot een vergelijkbare strategie als in de Verkenning is uiteengezet. De kanttekeningen die de WRR heeft bij enkele karakteristieken van de Verkenning, hebben derhalve eveneens betrekking op de activiteiten die de Europese Commissie op basis van de besluiten van de Europese Raad zal gaan ondernemen. 


\subsection{OPBOUW RAPPORT}

De raad is gevraagd te adviseren over de bestuurlijke consequenties van duurzame ontwikkeling. De vraag naar de bestuurlijke vormgeving hangt natuurlijk in hoge mate samen met de opvatting die over duurzame ontwikkeling wordt gehuldigd. Daarom is het noodzakelijk hier allereerst aandacht aan te besteden. Dat gebeurt in hoofdstuk 2. Naar zal blijken, meent de raad - in afwijking van het uitgangspunt dat in de Verkenning is neergelegd - dat het voor een goede vormgeving van het beleid ongewenst is om uit te gaan van een te omvattend begrip duurzame ontwikkeling.

De zienswijze van de raad heeft gevolgen voor de manier waarop inhoud moet worden gegeven aan de relatie tussen wetenschap en beleid, en de mede hierop te richten beleidsvorming. Hoofdstuk 3 handelt hierover. In hoofdstuk 4 gaat de raad vervolgens in op de bestuurlijk-institutionele implicaties die de Verkenning met zich meebrengt. Naar het oordeel van de raad staan deze op gespannen voet met de bestuurlijke vernieuwing zoals die gaande is, en spreken er alomvattende bestuurlijke ambities uit die niet realistisch zijn. In hoofdstuk 5 schetst de raad - gegeven het beschikbare zeer korte tijdsbestek - enkele hoofdlijnen van de bestuurlijke veranderingen die op grond van zijn zienswijze op duurzame ontwikkeling noodzakelijk zijn. In hoofdstuk 6 tot slot worden de bevindingen en aanbevelingen samengevat. 


\section{DUURZAME ONTWIKKELING: TUSSEN WAARDE EN METABEGRIP}

\subsection{GROEIENDE POPULARITEIT}

De aandacht die de commissie-Brundtland in haar rapport Our Common Future (1987) vroeg voor duurzame ontwikkeling, heeft wereldwijd een grote weerklank gevonden en aanleiding gegeven tot grote activiteit, zowel wetenschappelijk, maatschappelijk als politiek-bestuurlijk. Wetenschappelijk leidde het tot indringende vragen, zoals: welke ecologische gevolgen van menselijk handelen zijn aantoonbaar, hoe omkeerbaar zijn deze, waaruit bestaat de biodiversiteit eigenlijk, zijn alle soorten even belangrijk, welke relaties bestaan er tussen de soorten, welke voorraden aan grondstoffen bestaan er, welke substituten hiervoor zijn aanwezig of te ontwikkelen, wat is de invloed van het armoedevraagstuk voor het milieu? Het zijn stuk voor stuk vragen die een uitstraling hebben op vele vakgebieden.

Ook maatschappelijk gezien, heeft duurzaamheid een grote doorwerking gekregen. Er zijn vele groepen opgekomen die willen bijdragen aan een duurzame wereld, en evenzo kwalificeren velen zichzelf of hun activiteit inmiddels als 'duurzaam'. Dit geldt bijvoorbeeld voor groepen boeren, bepaalde steden of chemische industrieën die zich hiermee willen onderscheiden van vroegere praktijken of van die van anderen. In het maatschappelijk debat wordt de kwalificatie 'duurzaam' vaak aangevoerd als argument voor het eigen gelijk, maar ook degenen die dat gelijk bestrijden, doen dit door te verwijzen naar duurzaamheid. Dit geldt bijvoorbeeld voor het debat over de biotechnologie. Politiek-bestuurlijk zijn er in internationaal verband tal van belangrijke acties ondernomen. In het verband van de Verenigde Naties zijn er bijvoorbeeld belangrijke verdragen gesloten om ernstige milieuproblemen het hoofd te bieden, zoals ten aanzien van het klimaat, de ozonproblematiek en de biodiversiteit. De Europese Unie heeft zich in het 'European Fifth Action Plan' gecommitteerd aan het streven naar duurzaamheid en de oEso heeft een 'Environmental Strategy for the First Decade of the 21st Century' en 'Guidelines for Multinational Enterprises' opgesteld. In Nederland wordt met de Milieubalansen en de Milieuverkenningen van het RIVM, en de 'National Accounting Matrix including Environmental Accounts' (NAMEA) van het CBS, een belangrijke basis verschaft voor het beleid, dat met de achtereenvolgende Nationale Milieubeleidsplannen van het ministerie van Volkshuisvesting, Ruimtelijke Ordening en Milieubeheer (VROM) vorm heeft gekregen. Het interdepartementale programma Duurzame Technologische Ontwikkeling (DTO) heeft op verschillende terreinen een impuls gegeven aan de technologische innovaties die vanuit het oogpunt van duurzame ontwikkeling gewenst zijn.

Duurzame ontwikkeling is dus onderwerp van een brede bewustwording, wordt inmiddels met veel onderwerpen in verband gebracht en is onderdeel gaan uit- 
maken van de grammatica waarmee een breed gedragsspectrum wordt gemotiveerd. Tegelijk gaat met deze brede bewustwording een zekere vervaging van de betekenis gepaard. 'Duurzame ontwikkeling' is een lastig begrip en wordt dan ook op uiteenlopende wijzen geïnterpreteerd. De betekenis die eraan wordt toegekend, heeft evenwel grote consequenties voor het beleid en de beleidsvoorbereiding. Om de benadering van de Verkenning te kunnen beoordelen, wordt in de volgende paragrafen dan ook nader op het begrip ingegaan.

\subsection{DUURZAME ONTWIKKELING ALS WAARDE}

Waar gaat het bij duurzaamheid om? De commissie-Brundtland, waaraan de Verkenning refereert, formuleerde het op zeer compacte wijze: de mensheid moet streven naar een ontwikkeling die recht doet aan huidige behoeften zonder die van komende generaties in het gedrang te brengen. Dit is niet alleen noodzakelijk omdat er als gevolg van menselijk handelen sprake is van uitputting van grondstoffen, milieuvervuiling en vermindering van de biodiversiteit, maar vooral omdat deze verschijnselen een zodanige omvang en snelheid hebben gekregen dat zij zich als een boemerang tegen de mensheid nu, en in de toekomst, kunnen keren. De ontwikkeling van de wereldbevolking, het huidige ondoordachte handelen en de zeer ongelijke verhoudingen in de wereld tasten niet alleen de bestaansvoorwaarden aan van veel mensen in met name de ontwikkelingslanden, maar op termijn ook die van het rijke Westen en van de volgende generaties. De indringende boodschap is dat handelingen die onherstelbare milieuschade aanrichten moeten worden nagelaten, dat vernieuwbare voorraden niet moeten worden verbruikt voorbij hun regeneratievermogen, dat van niet-vernieuwbare voorraden voldoende moet worden overgelaten voor komende generaties en dat de biodiversiteit intact moet worden gelaten. Ultieme grenzen dienen derhalve te worden gerespecteerd. Hiermee formuleerde de commissie-Brundtland een nieuwe waarde, die uitdrukt dat het ecologisch draagvlak door het menselijk handelen niet in gevaar mag worden gebracht. Aldus sprak ze zowel Noord als Zuid aan en oversteeg ze de belangentegenstelling tussen de ontwikkelde en ontwikkelingslanden. De kracht van deze nieuwe waarde is immers dat wordt gewezen op de principiële lotsverbondenheid die er via het ecologisch substraat bestaat tussen arm en rijk, én tussen nu en later. De zeer scheve inkomensverhoudingen in de wereld zijn niet alleen laakbaar uit rechtvaardigheidsoverwegingen, maar armoede is vanwege de zeer negatieve ecologische effecten ook uitermate bedreigend voor de rijke industrielanden, evengoed als het overmatige beroep dat de rijke landen doen op grondstoffen en dergelijke, de ontwikkelingsmogelijkheden van de armeren beperkt. Evenzo worden de keuzemogelijkheden voor de nog ongeborenen beperkt door uitputting van schaarse hulpbronnen en onomkeerbare milieuschade die nu wordt aangericht. De waarde 'duurzame ontwikkeling' wijst kortom op de op het ecologisch substraat gebaseerde samenhang tussen rijk en arm en tussen nu en later en wijst op de noodzaak van een betere balans tussen de in het geding zijnde behoeften. 


\subsection{DUURZAME ONTWIKKELING ALS METABEGRIP}

De commissie-Brundtland liet het in Our Common Future niet bij het negatief normeren van gedrag in de zin van "geen gedrag waardoor het ecologisch substraat in het geding komt". De commissie stelde in haar rapport eveneens dat in de meest brede zin het oogmerk van duurzame ontwikkeling is "harmonie te bevorderen tussen mensen onderling, en tussen mens en natuur” (1987: 65). Dit vereist - zo wordt gesteld - een politiek systeem dat effectieve participatie van de burger in de besluitvorming mogelijk maakt, evenals een economisch systeem dat een surplus en technische kennis genereert op een duurzame basis, een sociaal systeem dat voorziet in oplossingen voor onharmonieuze ontwikkelingen, een productiesysteem dat de ecologische basis respecteert, een technisch systeem dat voortdurend nieuwe oplossingen zoekt, een internationaal systeem dat duurzame handels- en financiële patronen stimuleert, en tot slot een flexibel bestuurssysteem met het vermogen tot voortdurende zelfcorrectie.

Deze voorwaarden voor een duurzaam evenwicht voor de aarde en haar bevolking, nu en in de toekomst, gaan echter veel verder dan een karakterisering van hetgeen nodig is aan beleid en gedragsveranderingen om een duurzaam evenwicht vanuit ecologisch perspectief te herstellen of te behouden. Met deze betekenisverlening krijgt duurzame ontwikkeling het karakter van een metabegrip, een principe dat erkent dat alle waarden, behoeften, instituties, tijds- en ruimteschalen met elkaar samenhangen en dat ervan uitgaat dat een evenwicht hiertussen ook wenselijk is. Het drukt de wenselijkheid uit van een wereld waarin vrede heerst, rechtvaardige verhoudingen bestaan, besluitvorming democratisch tot stand komt, mensenrechten worden gerespecteerd en ecologische desiderata het materiële welvaartsstreven beteugelen. De functie van duurzaamheid in deze zin is dat het attendeert op integraliteit: uiteindelijk hangt alles met alles samen, en de mensheid dient van dit besef doordrongen te zijn. Zo gezien, wordt duurzame ontwikkeling het verbindende principe tussen alle activiteiten van de wereldgemeenschap die stoelen op waarden zoals rechtvaardigheid, welvaart, democratie, milieu en natuur, zowel op mondiaal niveau als, via de nodige schakelingen, uiteindelijk ook op lokaal niveau. In deze betekenis van harmonie typeert duurzaamheid niet alleen het geheel, maar evenzeer de relaties tussen en binnen de onderdelen.

In de Verkenning wordt duurzame ontwikkeling vooral in deze zin geïnterpreteerd. Hieraan kleeft echter het gevaar dat door het overheidshandelen een richtinggevende betekenis van duurzame ontwikkeling verloren gaat. Wanneer in dit verband alle mogelijke overheidshandelen van het adjectief 'duurzaam' wordt voorzien, suggereert dit een kwaliteit die niet noodzakelijkerwijs verband houdt met duurzaamheid vanuit ecologisch perspectief. Dit werkt verwarring in de hand ten aanzien van een onderwerp waar helderheid juist is geboden. De raad pleit er daarom voor vast te houden aan duurzaamheid als waarde in de eerstgenoemde betekenis die de commissie-Brundtland eraan gaf (zie par. 2.2). Kortom: een waarde die milieupreferenties en een hiermee samenhangend langetermijn- 
denken wil articuleren en versterken. Deze stellingname wordt in de volgende paragraaf nader toegelicht.

\subsection{DUURZAME ONTWIKKELING IN DE VERKENNING}

Op grond van duurzaamheid als eigenstandige doelstelling moet een samenhang tot stand worden gebracht tussen de economische, sociaal-culturele en ecologische aspecten. Dat is de centrale invalshoek van de regering in de Verkenning. Dit impliceert dat ernaar wordt gestreefd om bij alle besluitvorming een systematische afweging te maken tussen de economische, sociaal-culturele en ecologische aspecten van nieuw beleid, gedifferentieerd naar ruimtelijke schaal en naar tijdsschaal. Het resultaat zou dan zijn dat uiteindelijk het beleid op alle onderdelen als duurzaam kan worden gekenschetst. Duurzaamheid wordt derhalve de koepel voor de volle breedte van het regeringsbeleid.

Hoewel de Verkenning zeker ook duurzaamheid als waarde hanteert, speelt het metabegrip hierin derhalve een overheersende rol. Hiermee raakt de betekenis van duurzame ontwikkeling echter steeds meer los van de oorspronkelijke ecologische inspiratie, en wordt het onder meer gebruikt om aan te geven dat handelingspraktijken op ieder beleidsgebied bestand moeten zijn tegen veranderingen in de context. Wanneer zo ongeveer ieder gedrag in termen van duurzaamheid kan worden gerechtvaardigd of daarmee in verband kan worden gebracht, verliest het begrip zijn onderscheidende betekenis. De observatie van 'de samenhang aller dingen' en de hierop stoelende wenselijkheid van harmonie kan moeilijk anders dan naar zichzelf verwijzen; er ligt immers geen inhoudelijke referentie in vervat. Een operationele betekenis in de zin dat er duidelijke prioriteiten worden gesteld tussen alle in het geding zijnde doelen, kan er niet uit worden afgeleid. De wereld wordt immers getekend door waarden- en belangentegenstellingen; besluitvorming kan niet anders verlopen dan via de casuïstiek, en bepaalde condities moeten nu eenmaal als gegeven worden geaccepteerd.

Is de heuristische betekenis van een holistisch integratieprincipe derhalve niet erg groot, anders ligt dit bij de wens om vanuit duurzaamheid als waarde onduurzaam geachte situaties of ontwikkelingen concreet te willen verminderen. In het geval van gespecificeerde ecologische problemen is de notie van samenhang vanzelfsprekend waardevol, omdat ze ertoe dwingt zich te vergewissen van de oorzaken, hierbij te hanteren prioriteiten, en dergelijke. 'Samenhang' kan pas betekenis krijgen vanuit een expliciete prioriteitstelling tussen doelstellingen, maar is daarbij altijd selectief en dus partieel. Oog voor samenhangen is zo gezien wel degelijk een voorwaarde om tot goed gerichte acties te kunnen komen. Wanneer men daarmee echter niet volstaat en alle handelen wil bezien in relatie tot elkaar en tot uiteindelijk eventuele ecologische problemen, zal de onvermijdelijke complexiteit of abstractie eerder leiden tot immobiliteit dan tot actie. Als alles als voorwaarde voor alles wordt gezien, kan gericht, en derhalve selectief, handelen niet meer tot stand komen. 
Wordt de beleidsvoorbereiding erop ingericht om alle denkbare momentane en dynamische samenhangen te toetsen, zoals de Verkenning wil, dan zou dit - als het al mogelijk is - bovendien een enorme ruis opleveren, ook voor de alledaagse beleidsproblematiek. Het zou ook de noodzakelijke prioriteitstelling gericht op duurzame ontwikkeling-als-waarde juist bemoeilijken. Om duurzame ontwikkeling in deze zin veilig te stellen, is het derhalve belangrijk de ecologische invalshoek scherp voor ogen te blijven houden en zo te voorkomen dat hij ondergaat in bestuurlijke complexiteit.

De raad acht het derhalve van groot belang dat de beleidsaandacht zich concentreert op duurzaamheid als waarde. Hierbij vormt de ecologische problematiek de invalshoek vanwaaruit de afwegingsvraagstukken met de hiervoor relevante andere domeinen ter discussie worden gesteld. Duurzaamheid als metabegrip daarentegen acht de raad géén goed uitgangspunt voor het beleid. Hij betreurt het dan ook dat juist deze betekenis zo'n belangrijke rol speelt in de benadering die in de Verkenning is gekozen. Regelmatig wordt in de Verkenning gesteld dat beleidsintegratie van alle aspecten een meerwaarde oplevert; waar deze uit zou blijken, blijft echter buiten het zicht. Dit is niet verwonderlijk. De alomvattendheid ontslaat immers nog niet van de noodzaak om te komen tot concrete doelstellingen als resultante van alle afwegingen. Maar wat kan dan de maatstaf zijn? De te maken keuzes kunnen niet worden afgeleid uit het algemene begrip en zullen in de praktijk steeds berusten op een waardering van de concrete doelstellingen zelf.

Niet alleen omwille van het belang van de ecologische problematiek en de hanteerbaarheid van het beleid zelf is het in de ogen van de raad nodig om toe te spitsen op duurzaamheid als waarde, maar ook om in nationaal en internationaal verband te komen tot gerichte coördinatie en samenwerking. Bij de omvattende betekenis die de Verkenning aan het begrip toekent, kan het gevolg zijn dat het ene land duurzaamheid vooral vertaalt naar het ecologische terrein, terwijl het andere juist de nadruk legt op het aanpakken van de vergrijzingsproblematiek of op goede voorzieningen op sociaal terrein. Een zinvolle discussie in internationaal verband is slechts mogelijk wanneer men de inspanningen op gemeenschappelijke probleemgebieden met elkaar kan vergelijken. Hiermee is niet gezegd dat ieder land ook dezelfde uitwerking moet geven aan de waarde duurzaamheid vanuit ecologisch perspectief. Voor ontwikkelingslanden is armoedebestrijding in dit verband vanzelfsprekend een cruciale opgave, terwijl dit voor Nederland bijvoorbeeld eerder de waterproblematiek betreft. Het is echter weinig aannemelijk dat de Nederlandse arbeidsparticipatieproblematiek - zoals in de Verkenning is uitgewerkt - in ontwikkelingslanden veel belangstelling zal ontmoeten.

De Verkenning laat duidelijk zien wat de gevolgen zijn van een te ruime opvatting van duurzaamheid. De onbepaaldheid ervan leidt tot keuzes die willekeurig aandoen. Enerzijds wordt een aanpak bepleit op probleemgebieden, zoals klimaat, water en biodiversiteit, die uit het oogpunt van duurzaamheid als waarde relevant zijn. Bij deze selectie rijst overigens wel de vraag waarom andere gebieden, 
zoals de milieuproblematiek in de landbouw, uitputtings- en conserveringsvraagstukken, niet zelfstandig zijn behandeld. Anderzijds wordt veelvuldig gesproken van duurzame ontwikkeling als een op zichzelf staande kwaliteit van (uitkomsten van) beleid binnen de economische en sociaal-culturele aspecten zelf. Wanneer opgaven als "het garanderen van het economisch groeipotentieel tegen de achtergrond van de vergrijzing van de bevolking", "het versterken van effectieve en efficiënte dwarsverbanden tussen de school-, zorg- en sociale systemen" of "het handhaven van de sociale cohesie tegen de achtergrond van de multiculturele samenleving, individualisering en vergrijzing" alle onder de vlag van duurzame ontwikkeling worden gebracht, verliest het begrip - zoals hiervoor al gesteld - iedere verbinding met de problematiek van het gepercipieerde ecologisch substraat. Duurzaamheid brengt dan een waaier van beleidsdoelstellingen bijeen die ieder hun eigen betekenis hebben, maar ook steeds tegen elkaar moeten worden afgewogen zonder dat duurzaamheid als metabegrip hierbij behulpzaam kan zijn. Vergelijkbare opmerkingen kunnen worden gemaakt over de in de Verkenning opgesomde duurzaamheidsindicatoren, die uiteenlopen van de inkomensverdeling, het aantal uitvallers in het onderwijs tot aan emissie van broeikasgassen. Het is consistent met de benadering van de Verkenning dat aan ieder van de ecologische, sociaal-culturele en economische aspecten indicatoren worden ontleend. Het komt de raad echter voor als moeilijk voorstelbaar dat toepassing van deze duurzaamheidsindicatoren niet gepaard zou gaan met een grote spraakverwarring. In hoofdstuk 5 (par. 5.1.5) wordt nog uitvoeriger ingegaan op de eisen die aan te ontwikkelen indicatoren gesteld moeten worden.

Willen landen of organisaties in nationaal of internationaal verband met elkaar kunnen samenwerken of elkaar kunnen aanspreken op hun prestaties, dan is dat langs de weg van de Verkenning eveneens moeilijk realiseerbaar. De raad twijfelt er dan ook ernstig aan of het tot zinvolle resultaten zal leiden wanneer de 180 deelnemende landen op de conferentie in Johannesburg totaal verschillende verkenningen inbrengen.

Met het voorgaande wil de raad vanzelfsprekend niet afdoen aan het belang om op vele beleidsterreinen rekenschap te geven van de noodzaak van een langetermijnperspectief. De belangen van bijvoorbeeld de toekomstige generaties moeten een voortdurend aandachtspunt zijn, zoals de raad in zijn rapport Generatiebewust beleid (1999) tot uitdrukking heeft gebracht. Dit perspectief heeft hij ook voor de sociaal-culturele en sociaal-economische dimensies aan de orde gesteld in de rapporten Doorgroei van arbeidsparticipatie (2000) en Nederland als immigratiesamenleving (2001), terwijl het rapport Ontwikkelingsbeleid en goed bestuur (2001) aandacht geeft aan de bestuurlijke aspecten in ontwikkelingssamenwerking op de lange termijn. Dit alles onder één algemene noemer te willen vangen, is naar de mening van de raad echter contraproductief.

Het voorgaande heeft als consequentie dat de raad het voor de Nederlandse beleidsdiscussie ontraadt om duurzaamheid als metabegrip te gebruiken en daarop het bestuurlijke systeem in te stellen. Het bevorderen van duurzaamheid van- 
uit ecologisch perspectief vergt nu eenmaal een andersoortig beleid en andere verantwoordelijkheden dan bijvoorbeeld het bereiken van een houdbaar pensioenstelsel. Voor andere terreinen zou kunnen worden gesproken van een 'houdbaar' of een 'generatiebewust' beleid. Het lijkt slechts zinvol om landenrapportages als in Johannesburg voort te zetten, wanneer duidelijke afspraken worden gemaakt over de diverse doelstellingen die aan de orde moeten zijn.

De raad pleit derhalve voor een back to basics in de Nederlandse beleidsdiscussie, voor concentratie op die vraagstukken waar naar huidige kennis en oordeel menselijke activiteiten leiden tot evident problematische milieugevolgen. Het vervolg van dit rapport is hierop toegespitst. Om tot verder en gericht handelen te kunnen motiveren, is duidelijkheid nodig over het handelen waartoe duurzame ontwikkeling in deze door de WRR gehanteerde betekenis noopt. Dit vergt veelal decompositie en specificatie. De beleidsvoorbereiding dient hiertoe zo te zijn ingericht dat er prioriteiten bepaald kunnen worden en de mogelijke handelingsperspectieven duidelijk worden. Hierover gaat het volgende hoofdstuk. 


\section{WETENSCHAP EN POLITIEK}

De manier waarop het begrip 'duurzame ontwikkeling' wordt gebruikt, heeft ook consequenties voor de relatie tussen wetenschap en politiek. Deze relatie staat centraal in dit hoofdstuk. Kan de wetenschap de zekerheden over ecologische grenzen leveren die de politiek nodig heeft om haar beleid te bepalen en te legitimeren (par. 3.1)? Het blijkt niet mogelijk een 'objectieve' milieugebruiksruimte vast te stellen. Politiek en beleid zullen, gebruik makend van de beschikbare kennis, de in het geding zijnde waarden en doelen altijd tegen elkaar moeten afwegen, zo is de bevinding in paragraaf 3.2 .

\subsection{GRENZEN: OBJECTIEF OF SUBJECTIEF?}

Een van de lastigste vraagstukken op het terrein van duurzame ontwikkeling is hoe de doelstellingen van beleid te bepalen. Om welke concrete doelen moet het gaan wanneer men duurzame ontwikkeling wil nastreven? Anders dan op veel andere beleidsterreinen is hier niet direct evident wat men wil. En wat is de aard van de maatstaf aan de hand waarvan men kan bepalen of er sprake is van een duurzame relatie of dat het menselijk handelen moet worden gecorrigeerd? In Our Common Future wordt er regelmatig op gewezen dat, wil er sprake zijn van een duurzame relatie, de ultieme ecologische grenzen moeten worden gerespecteerd. Aangezien de natuur geen signaleringsmechanisme heeft waaruit voor iedereen ondubbelzinnig blijkt waar en wanneer een duurzame relatie overgaat in een onduurzame, ziet de commissie-Brundtland het dan ook als een belangrijke opgave voor de wetenschap om die ultieme grenzen vast te stellen.

Dat er in abstracto natuurwetenschappelijke randvoorwaarden voor het gedrag bestaan, lijkt evident. Ultiem gesproken moet de mensheid het immers doen met het beschikbare biotische en abiotische substraat. Het is echter een heel andere kwestie om in concreto te bepalen of deze grenzen zijn bereikt, of wellicht al zijn overschreden, dan wel of ze spelen op een termijn die ver voorbij de tijdshorizon ligt die voor de besluitneming relevant is. Er zijn en worden veel pogingen gedaan om hierin inzicht te verwerven. Zo is in Nederland een tijdlang het begrip 'milieugebruiksruimte' gehanteerd: de door ecologische grenzen bepaalde ruimte waarbinnen het menselijk handelen zich kan afspelen. Deze wetenschappelijk te bepalen ruimte zou tegelijk de marges aangeven waarbinnen de politiek keuzes kan maken.

Op dit onderwerp is de raad ingegaan in zijn eerdere rapport Duurzame risico's (1994). Hij wees er in dit rapport op dat kennis en kenbaarheid hun beperkingen kennen. Beschikbare kennis is immers veelal fragmentarisch van aard en de (dynamische) interacties tussen de verschillende deelelementen van het 'systeem aarde' vallen buiten het menselijk kenvermogen; dit laatste geldt ook voor de vraag hoe die interacties de stabiliteit of instabiliteit van het systeem aarde beïnvloeden. Bovendien zijn de begrippen 'stabiliteit' en 'instabiliteit' op dit niveau 
uiterst kwestieus. De raad wees in dit verband ook op het onderscheid tussen herhaalbare en unieke systemen. Unieke systemen worden gekenmerkt door een veelheid van vaak onbekende positieve en negatieve terugkoppelingen tussen deelsystemen, waardoor saldo-uitspraken over (in)stabiliteit niet gedaan kunnen worden. Dit geldt natuurlijk bij uitstek voor het systeem aarde. Waar bijvoorbeeld de aanwezige biodiversiteit in de verste verte nog niet wetenschappelijk in kaart is gebracht - schattingen lopen uiteen van 5 tot 8 o miljoen soorten, terwijl er 1,7 miljoen zijn beschreven (WRR 1994: 98) - en de samenhang tussen de soorten slechts fragmentarisch is onderzocht, kunnen moeilijk uitspraken worden gedaan op het systeemniveau. Bestaand inzicht heeft slechts betrekking op individuele soorten en gebieden. Hoeveel van deze biodiversiteit, welke soorten erbinnen en in welke vorm, moeten worden gezien als randvoorwaarde voor menselijke overleving, is een vraag die - in elk geval naar de huidige stand van kennis - niet kan worden beantwoord. Wanneer (on)gewenste ontwikkelingen op dit concrete niveau in verband worden gebracht met desiderata ten aanzien van het systeemniveau, namelijk handhaving van de biodiversiteit, is het dan ook onvermijdelijk dat andere overwegingen - waardetoekenning aan soorten, ethische of voorzichtigheidsoverwegingen - dan uitsluitend objectief-wetenschappelijke hun intrede doen.

\section{Samengaan kennis en oordeel}

Dat objectieve kennis en normatief oordeel onvermijdelijk samengaan, kan ook met een ander voorbeeld worden geillustreerd. Of het verbruikstempo van een grondstof een problematisch niveau heeft bereikt, hangt af van de voorraad van die grondstof, van het tijdig beschikbaar komen van substituten en van het tempo van technologische ontwikkeling. Om toekomstige uitputting te kunnen vaststellen, is niet alleen een, moeilijk bereikbaar, definitief inzicht noodzakelijk in de ontwikkeling van de vraag, de voorraden en hun prijsontwikkelingen en economisch/technologische winbaarheid, maar ook in de mogelijke alternatieven en de technologische mogelijkheid van aanwending. Bij verwachtingen omtrent dit laatste spelen ook beredeneerd optimisme of pessimisme een rol.

Ook als kennis wél voorhanden is, vloeit hier echter nooit rechtstreeks een randvoorwaarde of doelstelling uit voort; kennis leidt niet automatisch tot een norm. Worden bepaalde natuurwaarden door menselijke activiteit bedreigd en willen we die behouden, dan zal altijd een oordeel moeten worden gegeven over de betekenis die in het licht van de aanwezige kennis aan de natuurwaarden moet worden gehecht. Dit oordeel moet vervolgens worden afgewogen tegen de kosten die ontstaan wanneer zou worden afgezien van de activiteiten die de natuurwaarden schade berokkenen. Weliswaar kan de wetenschap aan deze afweging bijdragen door, via allerlei waarderingsmethoden, in beeld te brengen wat de kosten en baten zijn van natuurbehoud versus natuurgebruik, maar zo'n waardering zal altijd slechts een beperkt inzicht geven in feitelijke voorkeuren en belangen.

De notie van objectief-wetenschappelijke grenzen, die in abstracte zin zo aannemelijk is, roept voor de vertaling naar concreet handelen derhalve ingewikkelde 
vraagstukken op. Het politieke en beleidsantwoord op deze vragen kan niet alleen door wetenschappelijk onderzoek worden bepaald, maar is mede afhankelijk van oordelen omtrent de in het geding zijnde waarden en al dan niet aanvaardbaar geachte risico's. Bij de afgrenzing tussen wat beschouwd moet worden als duurzaam dan wel onduurzaam gaat het dus om zowel wetenschappelijke bemiddeling als de interpretatie hiervan vanuit normatieve overwegingen. Het domein van de wetenschap en van de normatieve opvattingen worden beide ook geregeerd door pluraliteit. Zoals een brede consensus over wenselijkheden zich alleen in uitzonderlijke omstandigheden voordoet, zo wordt ook de wetenschap vaak gekenmerkt door rivaliserende theorieën. Zelfs als over bepaalde feiten niet valt te twisten, zal de interpretatie ervan in de vorm van theorieën en interpretatiekaders uiteenlopen en is er sprake van verschillende paradigma's. Ook kennen beide bronnen van oordeelsvorming een dynamisch verloop. Zo gaf het aanvankelijke wetenschappelijk inzicht over de relatie tussen verzuring en vitaliteit van de bossen aanleiding tot grote onrust. Sindsdien is dit inzicht echter aanmerkelijk genuanceerd en blijkt de relatie bovendien veel complexer dan eerder werd aangenomen. Ook opvattingen evolueren. Stond Nederland in West-Europa eerst vrijwel alleen met zijn opvatting dat de risico's van kerncentrales voor elektriciteitsproductie in eigen land onaanvaardbaar zijn, sommige andere landen blijken deze mening nu ook schoorvoetend in te gaan nemen.

\section{Kiezen in onzekerheid}

Beperkte kennis en kenbaarheid, pluraliteit en dynamiek geven aan dat het allerminst een vanzelfsprekende activiteit is om de notie van bestaande grenzen - en derhalve objectieve randvoorwaarden - te vertalen naar doelstellingen voor concreet handelen. Om te bepalen wat beschouwd moet worden als het te respecteren ecologisch substraat, is een beoordeling nodig van de wetenschappelijke kennis, zowel de bestaande positieve kennis als de onzekerheden die deze laat. Controversialiteit omtrent wat in het licht van die kennis moet worden gedaan of nagelaten, is hieraan inherent. In plaats van dat er ondubbelzinnige ecologische grenzen kunnen worden aangewezen waaruit vanzelfsprekend een bepaald gedrag kan worden afgeleid, gaat het er bij duurzame ontwikkeling om beleid te voeren in een situatie van fragmentarisch inzicht, grote onzekerheidsmarges, uiteenlopende en veranderende verwachtingen en waarderingen. Het volgende hoofdstuk gaat hier uitvoeriger op in.

Voor het maken van politieke keuzes en het voeren van beleid is dit een lastige propositie. Het is ontegenzeggelijk veel eenvoudiger om ingrijpende maatregelen te legitimeren door te verwijzen naar omstandigheden die onomstotelijk hiertoe dwingen, dan dit te doen in termen van voorkeuren en een taxatie van onzekerheden en risico's. Juist op milieugebied is hier sprake van een dilemma. Aan de ene kant speelt het beroep op wetenschappelijke kennis een zeer belangrijke rol. Omdat de verschijnselen waar het om te doen is vaak alleen maar door specialisten kunnen worden waargenomen, moet de politiek zich wel in belangrijke mate verlaten op de wetenschap. Aan de andere kant levert die wetenschap niet de gewenste absolute uitspraken op. Integendeel, politiek en beleid zien zich gecon- 
fronteerd met rivaliserende theorieën en op zijn best conditionele uitspraken, voorzien van kansaanduidingen en geëxpliciteerde inherente onzekerheden. Beide domeinen, dat van de politiek en het beleid en dat van de wetenschap, spreken een verschillende taal en de spanning ertussen wordt eerder groter dan kleiner.

Deze spanning komt pregnant tot uitdrukking in de manier waarop wordt omgegaan met risico's. De wetenschap levert regelmatig informatie op, in de vorm van hypothesen of inschattingen met betrekking tot risico's. Het beleid daarentegen wil zekerheden. De aanvaardbaarheid van risico's in de politieke besluitvorming is dan ook zeer gering (zie bijv. de roep om 'zero tolerance' ten aanzien van de voedselveiligheid). Dit vertaalt zich weer in een toenemende druk om onconditionele uitspraken te doen (bijv. door gasboring in de Waddenzee te binden aan een wetenschappelijk aan te tonen nulrisico voor de ecologische kwaliteit van de zeebodem). Deze paradox plaatst niet alleen de wetenschap, maar ook de politiek in een moeilijke positie; hij onderstreept ook de verantwoordelijkheid van de politiek. Het moeten beslissen in onzekerheid is de normale conditie geworden. Ieder afwegingsresultaat impliceert altijd dat er risico's worden genomen en ook de afweging zelf wordt gestuurd door voorkeuren die aanvechtbaar zijn. Risico's moeten dus worden aanvaard; een onvermijdelijkheid die door de raad in zijn eerdere rapport over duurzame ontwikkeling tot uitdrukking is gebracht in de titel: Duurzame risico's; een blijvend gegeven.

De Verkenning van de regering wekt de indruk dat er, gezien vanuit duurzaamheid, een ondubbelzinnige koers bestaat van waaruit de tot stand te brengen beleidssamenhangen en de aard van de samenwerking rechtstreeks kunnen worden afgeleid. Deze indruk moet naar de mening van de raad worden vermeden. Het zozeer benadrukken van 'samenhang' en 'samenwerking', de in dit kader te ontwikkelen 'duurzame-ontwikkelingsbeoordeling' en 'duurzaamheidsbalans' en het veelvuldig gebruik van duurzaamheid als adjectief voor beleidsonderdelen, suggereren dat het ultieme doel gegeven is en dat de opgave er vooral één is van afstemming van de beleidsonderdelen hierop. Dit versluiert echter de noodzaak van de politieke keuzes die moeten worden gemaakt en het miskent het altijd controversiële karakter van die keuzes. De wetenschap kan niet de pretentie hebben noch de verantwoordelijkheid worden toebedeeld om de 'objectieve' milieugebruiksruimte te definiëren. Dit accentueert de plicht van politiek en beleid om - zo goed mogelijk gebruikmakend van de beschikbare kennis en na afweging van de in het geding zijnde waarden en doelen - dit wel degelijk in subjectieve en tegelijk navolgbare zin te doen.

De raad meent derhalve dat de vernieuwing van de nationale strategie die op deze Verkenning zal volgen, ook ter wille van de publieke discussie veel explicieter moet zijn over de politieke aspecten van duurzame ontwikkeling, en hiermee over de dilemma's die in het geding zijn. Zichtbaar moet worden gemaakt welke concrete doelstellingen op ecologisch terrein voor het beleid zijn gekozen, welke kennis aan die keuzes ten grondslag ligt, maar ook welke onzekerheden en risico's daaraan inherent zijn, en welke afwegingen zijn gemaakt ten opzichte van de 
doelstellingen op de relevante andere gebieden. Het belang van deze expliciete afwegingen komt in de volgende paragraaf aan de orde.

\subsection{DE BELEIDSVOORBEREIDING: MULTIDIMENSIONALITEIT EN AFWEGING}

De regering wijst er in de Verkenning terecht op dat het streven naar duurzame ontwikkeling afwegingen vergt; in feite vormt dit de kern van het document. Natuurlijk doen zich soms win-win-situaties voor, waarbij de uitkomst voor alle betrokkenen positief is. Zo zijn er veel voorbeelden waar energiebesparing en het verminderen van lekverliezen, gezien op overzienbare termijn, kosteneffectief zijn. In de meeste andere gevallen echter zijn trade-offs onontkoombaar, waarvoor het soms zelfs nodig is milieu- en natuurwaarden onderling af te wegen. Omdat het hier gaat om concurrerende waarden, zal de uitkomst afbreuk doen aan wat wenselijk zou zijn op grond van deze waarden afzonderlijk. De uitkomst is derhalve altijd een optimum, waarbij de absolute ideaalwaarden van alle conflicterende doelstellingen nooit gelijktijdig te verwezenlijken zijn. De beperkte instrumentruimte, onvolledig gearticuleerde preferenties en veelal tegenstrijdige belangen liggen hieraan ten grondslag.

\section{Afweging resulteert in haalbaar te achten doelstellingen}

Het ware wenselijk hierover geen misverstand te laten bestaan en de streefwaarden voor de doelstellingen vanuit de afweging zo concreet mogelijk aan te geven. Dat toont wat de ambitie is, gegeven de mogelijkheden. In de Verkenning wordt als doelstelling van het energiebeleid aangegeven het streven naar een energiegebruik dat 'nu en in de toekomst klimaatneutraal' is. De vooralsnog zeer bescheiden reductiedoelstellingen van broeikasgassen die in het kader van het KyotoProtocol in Bonn en Marrakech voor de periode 2008-2012 overeengekomen zijn (als die al gehaald worden, wat door de Algemene Rekenkamer (2002) voor Nederland sterk wordt betwijfeld), zullen in het licht van de recente rapportage van het Intergovernmental Panel on Climate Change (IPCC 2001) echter allerminst in staat zijn om antropogene klimaatverandering te voorkomen. Deze doet zich volgens het IPCC nu al voor. Ook al zouden de emissiereducties op de zeer lange termijn zodanig zijn dat te zijner tijd het berekende veilige niveau wordt bereikt, dan zou dit verdere klimaatverandering in de tussenliggende periode niet hebben kunnen voorkomen. De afwegingen die de betrokken partijen in het kader van het Kyoto-Protocol hebben gemaakt, resulteerden derhalve in een streefwaarde waarbij kennelijk een zekere klimaatverandering voor lief wordt genomen, gegeven de sociaal-economische kosten die in het geding zijn bij verdergaande maatregelen. Maar gegeven deze uitkomst dient vervolgens de doelstelling van het energiebeleid niet meer te worden gepresenteerd in termen van volledige genoegdoening van het desideratum 'voorkomen van klimaatverandering'. Die doelstelling wordt kennelijk niet haalbaar geacht, gegeven andere concurrerende doelstellingen.

De weging tussen milieu- en natuurwaarden, of tussen deze en sociaal-economische waarden, zal - zoals gesteld in de vorige paragraaf - keer op keer het karakter hebben van een dilemma; absolute grenzen ontbreken immers. Het is bovendien nooit belangenneutraal. Dit geldt in intragenerationeel, maar evenzeer in intergenerationeel perspectief. Vanuit welvaartstheoretisch perspectief gaat het er hier- 
bij om dat het welvaartsniveau (breed opgevat) van de toekomstige generaties niet lager mag zijn dan dat van de huidige generatie. Waar toekomstige generaties zelf hun stem niet kunnen laten horen, is het aan de huidige generatie om ter wille van de toekomstige generaties zelfbinding te betrachten. De raad stelde dit ook in zijn rapport Generatiebewust beleid (WRR 1999). In het op de toekomst gerichte beleid moet daarom een grote voorzichtigheid worden betracht in de afweging en uitruil van de verschillende welvaartsaspecten. Hierbij dienen zich vragen aan als in hoeverre men milieu- en natuurkapitaal mag opofferen voor menselijk en technologisch kapitaal. Bij de beantwoording van deze vragen moeten - op grond van onbekendheid dan wel aanwezige risico's - via het voorzorgsbeginsel eventuele ondergrenzen ten aanzien van het milieu- en natuurkapitaal worden gehanteerd. In feite vertolkte de raad hiermee zijn standpunt in de discussie tussen strong en weak sustainability (zie bijv. Pearce en Atkinson 1995; Den Butter, Hofkes en Verbruggen 1994). De Brundtland-definitie van duurzaamheid kan namelijk zo geïnterpreteerd worden dat beneden bepaalde grenzen niet verder mag worden ingeteerd op de verschillende onderdelen van het milieukapitaal; er mag dan dus geen uitruil plaatsvinden met andere welvaartsdoelstellingen (strong sustainability; ecologische duurzaamheid). In het voorgaande is echter al aangegeven dat het onmogelijk is om, op basis van natuurwetenschappelijke en ecologische kennis, dit soort ondergrenzen aan te geven. Natuurlijk kan er, met veiligheidsmarges, wel in bepaalde domeinen consensus ontstaan over niet te overschrijden ondergrenzen (vgl. de ozonproblematiek). Over het algemeen echter heeft de beschikbare kennis er bij veel milieuthema's (nog) niet toe geleid tot de opvatting dat definitieve ondergrenzen zijn bereikt, wordt gedeeld. In die zin is het uitgangspunt van uitruilmogelijkheden tussen de verschillende welvaartsaspecten alleszins valide. Alleen, zo waarschuwde de raad, bestaat er grote onzekerheid over toekomstige preferenties en rendement op technologie- en menselijk kapitaal. Een generatiebewust duurzaamheidsbeleid maant dan ook tot voorzichtigheid over die uitruilmogelijkheden.

Hoewel de regering deze noodzaak tot afweging in algemene zin ook onderkent, blijkt hiervan nog weinig in de gepresenteerde uitwerking op de verschillende thema's. Deze bestaat in hoofdzakelijk uit een opsomming en nevenschikking van de huidige doeleinden; de afweging zelf ontbreekt (nog). Duurzame ontwikkeling gebiedt, in de ogen van de raad, vooral tot een procedure die zodanige eisen stelt aan de beleidsvoorbereiding dat een zo scherp mogelijk zicht ontstaat op de trade-offs. Op basis hiervan moet immers de politieke afweging plaatsvinden tussen de ecologische waarden en de waarden die de schade veroorzakende activiteiten met zich meebrengen, in huidig en in dynamisch perspectief. De uitwerking die de WRR hieraan voorbeeldsgewijs gaf in zijn rapporten Duurzame risico's en Generatiebewust beleid lijkt de raad voor het proces van beleidsvoorbereiding nog steeds de hiertoe te begane weg. Deze benadering systematiseert als het ware het zoekproces dat aan besluitvorming vooraf dient te gaan. Uitdrukkelijk uitgangspunt hierbij was dat er in een context van risico's en onzekerheid verschillende opvattingen bestaan over duurzaamheid. Waarderingen van menselijke activiteiten worden bepaald door opvattingen over acceptabele risico's ten 
aanzien van zowel milieu als maatschappij. De verschillen in opvattingen zijn terug te voeren op cultureel en politiek bepaalde verschillen in de interpretatie van beschikbare wetenschappelijke informatie. Om tot handelen te kunnen komen, dient deze wetenschappelijke informatie - inclusief die over onzekerheden en risico's - daarom altijd maatschappelijk te worden geïnterpreteerd. De uiteenlopende percepties en bereidheid tot acceptatie van de verschillende risico's dienen vervolgens te worden vertaald in zo concreet mogelijke alternatieve handelingsperspectieven, dat wil zeggen: doelstellingen, te hanteren instrumenten en hun mogelijke gevolgen. Op deze wijze kunnen de mogelijke dilemma's en afwegingen, ook tussen heden en toekomst, zichtbaar worden gemaakt. Meerwaarde van deze benadering is, in de ogen van de raad, dat de bij het politieke proces betrokkenen zo worden geconfronteerd met de mogelijke consequenties ten aanzien van het milieu en ten aanzien van de activiteiten die hierop van invloed zijn.

Deze vorm van beleidsvoorbereiding verduidelijkt het spectrum van keuzemogelijkheden dat ontstaat wanneer duurzame ontwikkeling serieus wordt genomen. Hij faciliteert zo de publieke discussie en de politieke menings- en besluitvorming. Vanzelfsprekend lost deze benadering het probleem van beperkte kenbaarheid, zeker waar het de langere termijn betreft, niet op. Wél kan worden verhelderd, en bespreekbaar worden gemaakt, welke beleidsposities bestaan bij de gegeven fragmentarische kennis, risico's, risicopercepties en onzekerheid, en tot welk handelen zij zouden kunnen leiden met welke mogelijke gevolgen. Neem het gebied van de voedselvoorziening. Hier beroepen niet alleen degenen die met zo efficiënt mogelijk gebruik van kunstmest en chemische gewasbeschermingsmiddelen willen produceren zich op duurzaamheid, maar ook degenen die hiervan juist af willen zien. In Duurzame risico's kon, tegen de achtergrond van de ontwikkeling van de wereldbevolking,vrij nauwkeurig worden aangegeven wat de ene dan wel de andere productiewijze impliceert voor de hoeveelheid natuur die in de verschillende wereldregio's eventueel voor voedselproductie zou moeten worden opgeofferd. Hiermee kon derhalve de trade-off tussen milieu en natuur naar regio's zichtbaar worden gemaakt en werden de implicaties van (uitblijvende) keuzes verhelderd.

Concluderend: het komt de raad als wenselijk voor dat de uiteindelijk te bepalen nationale strategie uitdrukkelijk probeert de keuzes die de politiek moet maken, te laten voortvloeien uit een expliciet gemaakte afweging tussen de alternatieve handelingsmogelijkheden voor de probleemgebieden. Door op deze manier, anders dan de Verkenning nu doet, de voor- en nadelen van die handelingsperspectieven naast elkaar te zetten, komen de dilemma's in beeld. Ook ontstaat er zicht op de redeneringen die aan de keuzes ten grondslag liggen, de prioriteiten die hierbij worden gehanteerd en de risico's die aanvaardbaar worden geacht. Om inzicht te krijgen in de beleidsalternatieven is het nodig dat de beleidsvoorbereidende kennisinstellingen per onderwerp gericht samenwerken. Omdat ook de economische en sociale consequenties, met alle bijbehorende trade-offs, in ieder handelingsperspectief in kaart moeten worden gebracht, is hierbij ook andere dan 
bèta-expertise nodig. Dit 'delta'-onderzoek - dat alpha-, bèta- en gamma-invalshoeken integreert - staat echter nog in de kinderschoenen, maar verdient ter wille van een zo goed mogelijke besluitvorming verdere ontwikkeling.

Het is dus niet mogelijk noch zinvol om vanuit een top-down-perspectief alle ontwikkelingen aan te sturen en met elkaar in verband te brengen. Politiek, beleid en wetenschap moeten leren van een case-by-case-benadering, waarbij op verschillende terreinen verschillende stakeholders betrokken zijn. Dit leidt ongetwijfeld tot verscheidenheid, maar hoeft anderzijds niet persé te leiden tot een palet van volledig los van elkaar staande handelingspatronen. Bovendien kan er door een goede afstemming, ook over de sectorgrenzen heen, van elkaars ervaringen geleerd worden. 


\section{BESTUURLIJK-INSTITUTIONELE ONTWIKKELINGEN EN RANDVOORWAARDEN}

De vorige hoofdstukken lieten zien dat het niet erg vruchtbaar is om allerlei doelstellingen en aspecten van overheidsbeleid onder te brengen onder één superdoelstelling, zoals 'duurzaamheid'. In dit hoofdstuk gaat het over de publieke besluitvorming en de betekenis van de karakteristieken daarvan voor een verdere ontwikkeling van het duurzaamheidsbeleid. Paragraaf 4.1 behandelt (de inherente beperkingen aan) het handelingsvermogen van de overheid, in contrast met wat de Verkenning hierover vooronderstelt. In paragraaf 4.2 gaat het vervolgens over de bestuurlijke vernieuwing die al gaande is en die deels langs andere lijnen verloopt dan de Verkenning voor ogen lijkt te staan.

\subsection{BEPERKINGEN AAN HET HANDELINGSVERMOGEN VAN DE OVERHEID}

Het 'integraliteitsdenken' van de Verkenning en de veelomvattende bestuurlijke ambities waarin dit uitmondt, stellen hoge eisen aan het handelingsvermogen van de overheid. Kenmerkend voor de Verkenningsnota is dat dit handelingsvermogen, en de ontwikkelingen daarin, weinig worden geproblematiseerd.

Er zijn echter belangrijke beperkingen aan het cognitie- en sturingsvermogen van de overheid. Deze beperkingen zijn van diverse aard. In de eerste plaats is de burger mondiger geworden en bedient hij zich ook van tal van mondige spreekbuizen en zaakwaarnemers. Ten tweede hebben processen van internationalisering en Europeanisering het handelingsvermogen van de nationale overheid aangetast. Ten derde heeft de overheid de afgelopen decennia ingezet op deregulering, privatisering en decentralisatie. Dat hiermee aan handelingsvermogen is ingeboet, is deels afgedwongen door de veranderende (nationale en internationale) omstandigheden, maar deels ook een eigen keuze geweest. Een groot programma van bestuurlijke vernieuwing is hiermee al gaande. Andere (private en publieke) partijen hebben de ruimte gekregen om meer verantwoordelijkheden te dragen. Deze ontwikkelingen zijn bekend en op tal van plaatsen verder uitgewerkt. Bovendien - en ten vierde - ontbreekt het in de bestuurlijke werkelijkheid hoe dan ook aan de in de Verkenning veronderstelde synoptische rationaliteit waarbij alle relevante aspecten continu op elkaar worden afgestemd en tegen elkaar worden afgewogen. Deze hang naar integraliteit versluiert dat er in de publieke arena altijd meervoudige, complexe en strijdige doelen in het geding zijn, die als regel niet in elkaars verlengde liggen maar om keuzes vragen. Bij het 'beleid maken' - de afwegingen en keuzes maken en daar bestuurlijk vorm aan geven - geldt vervolgens dat informatietekorten en informatiehantering een alomvattende beleidsrationaliteit, als deze al wenselijk zou zijn, ten ene male onmogelijk maken. Het cognitievermogen van een centraal sturend centrum is altijd beperkt, zoals bestuurskundigen als Simon en Lindblom (1965) al in de jaren zestig lieten 
zien. Dit pleit ervoor in te zetten op een decompositie en een vereenvoudiging van het duurzaamheidsbeleid dat door de regering wordt voorgestaan.

\section{Multi-actor samenleving}

De huidige samenleving wordt wel gekenschetst als een multi-actor samenleving, die op sommige punten andere eisen stelt aan het overheidshandelen. Het is nuttig deze punten uit te werken, omdat ze mede de zienswijze van de raad vormen over de bestuurlijke vernieuwing die in het duurzaamheidsbeleid mogelijk en gewenst is (hfdst. 5). In hoofdstuk 2 is er al voor gepleit om het duurzaamheidsbeleid te focussen op de ecologische waarden en de afwegingen die deze met zich meebrengen. In beginsel is dit al de eerste 'vereenvoudigingsslag' die gemaakt moet worden om te komen tot een gericht, operationeel en mobiliserend beleid.

Kenmerkend voor de besluitvorming in Nederland - als coalitieland - is dat er veel energie wordt gestoken in de interne coördinatie: de bestuurlijke procedures om te komen tot een bepaalde beleidsinzet. Dit komt tot uitdrukking in relatief veel overleg, afstemmingsprocedures en een trage besluitvorming (structuurschema's e.d.). Typerend is ook dat er vele beleidsnota's (bijv. de NMP's in het milieubeleid) worden voortgebracht, maar dat Nederland meestal niet voorop loopt bij het implementeren en handhaven van concreet beleid. Inherent hieraan is een zeker onvermogen van de nationale overheid om prioriteiten te stellen. Ook de huidige Verkenning is hier een voorbeeld van. Zij bevat veel aandacht voor procedures voor interne afstemming en een bijbehorend streven om ook extern commitment te vinden voor het resultaat (organiseren van samenwerking). De nadruk op deze interne afstemming heeft als resultaat een beperkte handelingsgerichtheid en gaat ten koste van de aansturing van het beleidsveld en de handhaving van het beleid. Het werkt ook onduidelijkheid in de hand over de verantwoordelijkheden.

Deze interne gerichtheid en gebrekkige externe coördinatie gelden ook voor de relatie met Europa. Wat intenties betreft, heeft Nederland veel slagkracht in Brussel, maar loopt niet altijd voorop als het aankomt op de implementatie.

Om in het duurzaamheidsbeleid tot een versterkte handelingsgerichtheid te komen, zijn informatie, beleidsanalyse, transparante afwegingskaders en doelmatig werken van groot belang. Hiernaast biedt, bij het ontwikkelen van beleid, een aanpak gericht op de decompositie van problemen in veel gevallen de grootste kans op succes. Dit geeft ook de meeste ruimte voor terugkoppelingen en leerprocessen in het beleid, door middel van monitoren en experimenteren. In zijn recente rapport Van oude en nieuwe kennis (WRR 2002) heeft de raad ervoor gepleit dat bij complexe beleidsproblemen en grote onzekerheid over toekomstige ontwikkelingen en samenhangen het accent niet wordt gelegd op uniforme en centralistische aanpakken ('in één keer uitrollen', zoals in het middelbaar onderwijsveld met het Studiehuis is gebeurd), maar op variëteit, evaluatie en (na verloop van tijd) selectie en verankering van die experimenten waarvan de resultaten het best bevallen. Om nieuwe ontwikkelingen te bevorderen moet de overheid variëteit toestaan. Dit moet dan wel gebeuren onder de voorwaarde dat van de 
ervaringen kan worden geleerd (via een goede opzet en evaluatie) en dat de doelstellingen van het beleid goed worden verankerd. Op die wijze kan worden geprofiteerd van de kennis die in de samenleving aanwezig is; ook kan worden geëxperimenteerd met verschillende benaderingen.

\section{Beleidsstapeling bemoeilijkt handhaving}

Vanuit dit gezichtspunt is het problematisch dat er bij het huidige beleid nogal eens sprake is van een veelheid aan strakke regelgeving ('beleidsstapeling'), die naleving en handhaving in de praktijk sterk bemoeilijkt. De raad is van mening dat dit onderwerp veel meer aandacht behoeft. Tegelijkertijd kan het voorkomen dat de inhoud van het beleid niet altijd (meer) in overeenstemming is met de afwegingen en inzichten die bestaan op het moment waarop de regels worden toegepast; zo worden nieuwe ontwikkelingen ontmoedigd. Bovendien wordt de naleving van de regels ondergraven, wanneer in de private sector de indruk bestaat dat zij niet berusten op een zinvolle afweging van de verschillende betrokken belangen en dat er mogelijk betere oplossingen, die niet worden gestimuleerd door een te statische overheidsregelgeving, voorhanden zijn (vgl. Scheltema 2002).

Een strakke sturing via regelgeving door de overheid draagt ook het gevaar in zich dat de verantwoordelijkheid voor het nemen van maatregelen in het belang van duurzame ontwikkeling uitsluitend bij de overheid ligt. Private organisaties richten hun aandacht vooral op de vraag hoe zij kunnen voldoen aan de eisen van het overheidstoezicht. Zij schuiven hiermee de eigen verantwoordelijkheid als het ware weg, terwijl zij doorgaans het beste in staat zijn om maatregelen te nemen en ook op die verantwoordelijkheid moeten worden aangesproken.

Omdat niet alles van regelgeving en handhaving kan komen, is het hiernaast van belang financieel-economische instrumenten in te zetten, zoals regulerende heffingen en (een experiment met) verhandelbare emissierechten.

\subsection{BESTUURLIJKE VERNIEUWING EN INSTITUTIONELE INNOVATIE IN EEN MULTI-ACTORSAMENLEVING}

De Verkenning stelt de normatieve vraag hoe de bestuurlijke vernieuwing die nodig is voor het duurzaamheidsbeleid dat in de nota wordt voorgestaan, handen en voeten kan worden gegeven. In dit licht is het goed om te constateren dat er in het overheidsbeleid in het algemeen al veel bestuurlijke vernieuwing gaande is. De overheid beperkt zich al lang niet meer tot de traditionele top-down-sturing. Het proces van bestuurlijke vernieuwing kan worden gezien als het antwoord op de beperkingen die een hiërarchisch overheidsbeleid ondervindt in een complexe, moderne (multi-actor)samenleving met mondige burgers en een voortgaande internationalisering. Het heeft al geleid tot processen van decentralisatie, privatisering, deregulering, enzovoort. Ook het patroon van bestuurlijke arrangementen heeft zich verruimd, met convenanten, publiek-private samenwerking en andersoortige betrokkenheid van stakeholders. In deze context is er geleidelijk aan een grotere ruimte ontstaan voor experimenten en variatie in het beleid (Hazeu 
2000a: 246; WRR 2002). Door mechanismen van variatie, monitoring en selectie moet er vervolgens van die experimenten worden geleerd. Dit element van 'beleidsleren' en 'learning by monitoring' (Sabel 1994) is van belang om niet te hoeven volstaan met een relativering van het synoptische besluitvormingsconcept. Het concept van beleidsleren impliceert dat de idee van een beperkt sturende overheid niet hoeft te worden vereenzelvigd met de 'kunst van het doormodderen' tussen de kortetermijnoriëntaties van politici en het langetermijnperspectief dat nodig is voor een zinvolle analyse van veel beleidsvelden en -problemen. Wanneer overheidsbeleid is ingebed in gevarieerde systemen van probleemgeoriënteerde expertise, onafhankelijke media, gedeelde besluitvorming, interactiegeoriënteerde systemen van verantwoording en andere checks and balances, kan korte termijn (partij)politieke competitie toch ook het karakter aannemen van het concurrerend werken aan de problemen op (middel)lange termijn.

\section{'Wicked problems'}

Steeds indringender ziet het duurzaamheidsbeleid zich geplaatst voor de zogenaamde wicked problems: milieuproblemen die gekenmerkt worden door een relatief grote onzekerheid over de causaliteiten en wél mogelijke enorme gevolgen hebben. Zoals in hoofdstuk 3 al is uiteengezet, impliceert het dat de besluitvorming (deels) in onzekerheid (over causaliteiten, effecten, termijnen, enz.) moet plaatsvinden. Toch zal er iets moeten worden gedaan; onzekerheden mogen er immers niet in resulteren dat van handelen wordt afgezien. Bestuurlijk gezien is het van groot belang dat bij 'grote onzekerheid' en 'langetermijneffecten' een strategische oriëntatie georganiseerd wordt. Niettemin is het, zo kan empirisch worden geconstateerd, de 'natuurlijke' neiging van beleidsmakers om bij de aanpak van de moeilijke (ecologische) problemen houvast te zoeken in het 'gekende' verleden, ook al biedt dit slechts schijnzekerheden. In de praktijk van het 'beleid maken' voelt men zich hiertoe genoopt vanuit het oogpunt van draagvlakvorming, verantwoording en legitimatie aan burgers (maar ook aan bedrijven, zaakwaarnemers en anderen). Ook bij beleidsvorming in onzekerheid is daarom de neiging groot om zo veel mogelijk te zoeken naar en aan te sluiten bij situaties waarmee de analogie nog het grootst is, te kijken naar de beleidsaanpak die daarbij is gevolgd, de lessen te trekken van wat er goed en minder goed is gegaan en ten slotte zo goed mogelijk een andere aanpak of modificatie ervan te beredeneren, waarmee de analogie stopt.

Het geleidelijk aan agenderen van de wicked problems heeft ook tot gevolg gehad dat inhoudelijke sturing en 'hard beleid' (regelgeving, financiële maatregelen) worden gecompleteerd met processturing en 'zacht beleid'. Zo kent het (internationale) duurzaamheidsbeleid al veel regelgeving (vogel- en habitatrichtlijn, nitraatrichtlijn, enz.), maar biedt het hiernaast de laatste jaren tal van voorbeelden van 'zacht beleid': convenanten en nieuwe overlegvormen. Twee voorbeelden van die nieuwe overlegvormen op nationaal niveau zijn de 'opgroening' van de SER (SER 2001) en het TOPS-overleg over Schiphol. Dit laatste is overigens mislukt, maar dat hoort bij de 'zoekende' aard van het leerproces waarmee bestuurlijke vernieuwing gepaard gaat. 


\section{Verankering duurzaamheidsbeleid}

Zowel in Nederland als daarbuiten is de inhoudelijke ecologische problematiek sinds de jaren zestig een omvangrijk beleidsterrein geworden. Ook buiten de overheid is de aandacht voor het milieu - soms tegen wil en dank - op zeer veel plaatsen geïnternaliseerd door private actoren en maatschappelijke organisaties. Logischerwijze volgde de stroomlijning en afstemming van de sectorale milieuwetgeving tot een overkoepelende kaderwet: de Wet algemene bepalingen Milieuhygiëne (WabM) uit 1987, later de Wet Milieubeheer (WM) uit 1993, gevolgd door verdere integratie van vergunningen (recent ook op EU-niveau door middel van de IPPC-richtlijn). Hiermee heeft zich een verschuiving voorgedaan naar bescherming van het milieu als eigenstandig, collectief goed; een verschuiving die uiteindelijk wordt gemarkeerd doordat de plicht tot milieubescherming is opgenomen in de Grondwet en in de doelstellingen van het EU-verdrag ("bescherming van de gezondheid van mens en milieu op een hoog niveau"). Niet langer moet voorgesteld milieubeleid, in casu milieuwetgeving, getoetst worden aan bestaande wetgeving, maar worden beleid en wetgeving op aanpalende beleidsterreinen aan de milieuwetgeving getoetst. We kunnen dus zonder twijfel zeggen dat duurzaamheid vanuit ecologisch perspectief als centrale waarde in het beleid is verankerd: er is een Ministerie voor Milieubeheer, een Milieuen Natuurplanbureau bij het RIVM dat systematisch informatie verzamelt over milieu- en natuurwaarden, verplichte milieu-effectrapportages (MER) bij grote investeringsprojecten, enzovoort.

Cases kunnen illustreren hoe 'ver' het beleid momenteel is. Sommige beleidsgebieden worden nog geregeerd door een stapeling van top-down-beleid, waardoor onvoldoende recht wordt gedaan aan het leerpotentieel. Ook worden soms onvoldoende consequenties verbonden aan de meer gehorizontaliseerde maatschappelijke verhoudingen. Onderstaande box schetst het nitraatbeleid als voorbeeld van een nog traditioneel functionerend beleid dat een stapeling van voorschriften laat zien, maar waar ook een modernere, meer op doelen gerichte benadering denkbaar is.

\section{De nitraatcase}

In 1991 heeft de EU de nitraatrichtlijn uitgevaardigd, waarbij ter bescherming van de grond- en oppervlaktewaterkwaliteit een bovengrens van $17 \mathrm{og} / \mathrm{ha}$ is vastgesteld voor de bemesting met organische mest. Deze richtlijn is in de verschillende landen van de EU op verschillende wijzen geïmplementeerd in de nationale wetgeving. In Nederland is de MINAS-wetgeving ingevoerd (Mineralen Aangifte Systeem), waarbij boeren het verschil moeten berekenen tussen de hoeveelheid stikstof die het bedrijf binnenkomt en de hoeveelheid die het bedrijf verlaat. Voor verschillende bodems en bedrijfssystemen zijn in MINAS voor deze verschillen kritieke waarden gedefinieerd, maar deze zijn alleen indirect en op ondoorzichtige wijze gerelateerd aan de kwaliteit van grond- en oppervlaktewater in termen van het nitraatgehalte. Dit heeft geleid tot veel onbegrip in de praktijk. Als de kritieke MINAS-waarden worden overschreden, dient een heffing te worden betaald. De overheid verzamelt, beoordeelt en toetst de berekeningen van de boeren en legt heffingen op in het geval van overschrijding. Dit is een omvangrijke administratieve taak die, getuige een recent rapport van de Algemene Rekenkamer (2001), niet goed kan worden uitgevoerd. 
Naast de MINAS-regelingen zijn er ook aparte regels voor het beperkt uitrijden van mest en voor het injecteren van vloeibare mest. Al deze regelgeving is gericht op middelen en niet op doelen. De gevolgde procedures zijn een voorbeeld van een door de overheid eenzijdig opgelegde regelgeving die door diezelfde overheid wordt gecontroleerd.

Een alternatieve benadering zou direct gericht kunnen zijn op het doel van de waterkwaliteit en niet op de middelen waarmee die kwaliteit kan worden bereikt, zoals nu. In dat geval worden boeren, of groepen van boeren in een gebied, afgerekend op het feit of ze die kwaliteit na verloop van tijd al of niet weten te bereiken. Een onafhankelijke instelling zou de waterkwaliteit kunnen controleren en zou overtredingen kunnen melden aan de overheid. Er zijn binnen de bedrijfsvoering veel manieren om het uitspoelen van nitraat naar grond- en oppervlaktewater te verminderen, zoals het verbeteren van de mestkwaliteit, het herhaaldelijk toedienen van mest in kleine hoeveelheden, het verleggen van het graasseizoen van de koeien, enzovoort. Een doelenbeleid in plaats van een middelenbeleid is transparanter voor de boeren en doet vooral ook recht aan hun ondernemerschap. Er zijn immers veel verschillende manieren om het waterkwaliteitsdoel te bereiken. Inventarisatie van deze manieren biedt de basis voor een gemeenschappelijke leerervaring van boeren en overheid, waarbij de wetenschap een intermediaire rol kan spelen.

De casus illustreert dat er beleidsgebieden zijn waar de bestuurlijke vernieuwing nog weinig voet aan de grond heeft gekregen. Ook waar de vernieuwing wel plaatsvindt, worden er niet altijd voldoende consequenties aan verbonden. Voor zover er sprake is van bestuurlijke vernieuwing in de zin van 'vermaatschappelijking van de politiek', is de keerzijde hiervan een 'verpublieking van private actoren'. Het delegeren van publieke verantwoordelijkheden naar andere actoren dan de centrale overheid, of het (zich door) hen toerekenen van publieke belangen, impliceert dat deze actoren publieke verantwoording moeten afleggen, dat zij moeten zorgdragen voor adequate en voor het publiek transparante vormen van verificatie. Zowel de overheid, maatschappelijke organisaties als individuele burgers hebben moeite met deze veranderende verhoudingen. Voor overheden is het soms lastig 'slechts' op doelen te sturen, gewend als ze waren ook de middelen voor te schrijven. Voor maatschappelijke organisaties is het soms verleidelijk te volstaan met lippendienst aan publieke taken. Zo dient 'maatschappelijk verantwoord ondernemen' meer in te houden dan een PR-aangelegenheid. Burgers blijven bij problemen toch de overheid verantwoordelijk houden, zonder zich af te vragen wat ze zelf zouden kunnen doen. Anders gezegd: een bestuurlijke vernieuwing die stoelt op de gedachte dat duurzame ontwikkeling niet de exclusieve verantwoordelijkheid van de overheid is, maar een waarde die iedereen aangaat, mag niet ontaarden in vrijblijvendheid.

\section{Convenanten, commitment en consultatie}

De ontwikkeling van het Nederlandse milieubeleid kan worden gezien als een zoektocht naar een nieuwe institutionele vormgeving van beleid volgens de logica van het 'leren door monitoren'. Het gaat hierbij om een methode voor het oplossen van een type beleidsproblemen waarvan erkend wordt dat niet-handelen onaanvaardbaar is, terwijl alomvattende oplossingen niet voorhanden of onwerkbaar zijn. Bij het zoeken naar (domeinoverstijgende) oplossingen voor dit 
type problemen moet ook in belangrijke mate een beroep worden gedaan op lokale kennis. In toenemende mate en in steeds eerdere stadia heeft de Nederlandse overheid hiertoe maatschappelijke organisaties - vervuilers, milieuactivisten - bij de beleidsontwikkeling betrokken. Met de doelgroepenbenadering, door middel van convenanten - publiekrechtelijke overeenkomsten tussen staat en koepelorganisaties, later individuele bedrijven - en door milieuorganisaties in te schakelen bij processen van kennisverwerving is bewust getracht om een commitment te creëren bij die organisaties, door met hen overleg te voeren over de wijze waarop de gestelde milieudoelen kunnen worden gerealiseerd.

In ditzelfde licht heeft ook een 'vergroening' van de SER plaatsgehad: in twee relevante commissies - voor Ruimtelijke Ordening en voor Duurzame Ontwikkeling - hebben milieuorganisaties een plaats gekregen naast de gebruikelijke drie partijen. Deze vorm van 'lichte institutionalisering' en andere innovaties in de bestuurlijke vormgeving hebben geleid tot een vernieuwde structuur die de verschillende partijen in staat stelt elkaars gedrag te monitoren en tegelijkertijd te bevorderen dat zij leren van gedeelde ervaringen. Hierbij worden interacties geëvalueerd en aangepast op basis van wederzijdse verwachtingen en worden gezamenlijke probleemoplossingen geformuleerd. De dimensie van monitoren mitigeert de kans op free riding en doublures; belangrijker echter is de dimensie van het leren: verbreding en verdieping van informatie en de uitwisseling van ervaringen. Door consultatie tussen de partijen te reguleren, kunnen de kosten van beleidsfalen worden geminimaliseerd en kunnen mogelijkheden om het beleid te verbeteren, worden geoptimaliseerd.

Deze institutionele vernieuwing is enerzijds het gevolg van de gebleken grenzen aan de handhaafbaarheid van een hiërarchisch beleid. Anderzijds is zij ontstaan doordat de sectorale weerstand tegen eenzijdig opgelegde, dwingende gebods- en verbodsbepalingen is toegenomen. Was de doelgroepenbenadering er in eerste aanleg vooral op gericht de door de wetgever bekrachtigde milieudoelstellingen effectief te implementeren, met de toenemende oriëntatie van het milieubeleid op een netwerksturing in multi-actorconstellaties wordt ook de afweging van de doelstellingen van beleid onderwerp van deze lichtere en flexibele vorm van beleidsleren door monitoren.

Het gebruik van convenanten en dergelijke kent echter drie problemen die hun legitimiteit in principe kunnen ondergraven; in het ergste geval leiden zij tot uitstel van principiële oplossingen in de milieuproblematiek. In de eerste plaats is het problematisch de door de minister gemaakte afspraken democratisch te controleren. Het - verticale - primaat van het parlement en de horizontalisering van de netwerkonderhandelingen staan op gespannen voet met elkaar. In de tweede plaats hadden de eerste convenanten geen duidelijke juridische status, waardoor het problematisch was de afspraken bij onvolkomen naleving af te dwingen. Deze laatste problemen worden tegenwoordig beter gekanaliseerd. In de derde plaats zijn convenanten met belanghebbenden er meestal op gericht om de milieu-efficiency te verbeteren en het milieubederf te verminderen, in zoverre 
als de belanghebbenden dit op basis van de bestaande technologie mogelijk achten. Dit kan de overgang naar een andere technologie in de weg zitten.

De genoemde bezwaren wegen zwaarder naarmate de aard van het probleem dat met het convenant wordt aangepakt, moeilijker wordt. Desondanks lijken veel convenanten redelijk goed te hebben gewerkt. Een toevoeging bij de nieuwste convenanten is de belangrijker rol van benchmarking.

\section{Schaalvergroting}

De bestuurlijke schaal van de milieuproblemen van de jaren zeventig (lucht, water en bodem) hadden bovenal een lokaal en regionaal karakter; de problemen konden dan ook met een relatief succesvol nationaal beleid tegemoet worden getreden. De nieuwe ecologische problematiek van klimaatverandering, water en biodiversiteit is fundamenteel anders van aard, in het bijzonder waar het de schaal betreft. Kenmerkend is dat:

1 de problemen in toenemende mate internationaal van aard zijn;

2 de gevolgen minder gelokaliseerd zijn (waardoor deze problemen niet slechts deelgroepen raken, maar vele burgers, zo niet iedere burger);

3 de effecten zich manifesteren op de lange termijn; en

4 de problemen omgeven zijn door diverse onzekerheden die niet allemaal door wetenschappelijke kennisverwerving kunnen worden weggenomen.

Uiteraard is het wenselijk dat grote, internationale milieuproblemen ook internationaal worden aangepakt. Met de schaalvergroting van de milieuproblemen zijn dan ook de institutionele niveaus waarop deze problemen tegemoet worden getreden, verschoven naar hogere bestuurlijke schalen. Inmiddels ligt de nadruk steeds meer bij Europese regelgeving en bij internationale afspraken. Europese Richtlijnen gaan boven de nationale wetgeving. Anders dan bij andere internationale verdragen is hier echter geen parlementaire discussie mogelijk over de vraag van ratificatie. Hiermee wordt niet alleen de nationale beleidsruimte ingeperkt, maar ontstaat er tevens een legitimatietekort. Ook in het geval van internationale afspraken moet immers een terugkoppeling naar en een verantwoording aan de nationale politiek plaatsvinden, de bestuurlijke schaal waaraan de democratische legitimiteit van internationale afspraken in eerste instantie is ontleend. De beleidsautonomie die de nationale overheid rest, ligt hierdoor steeds meer bij de uitvoering van het beleid. Dit versterkt de noodzaak om op dat moment legitimatie te verwerven door burgers, bedrijven en andere betrokkenen met hun 'lokale kennis' te betrekken bij de implementatie van het beleid.

Hiernaast dienen ook de verdelingsvraagstukken die met diverse internationale afspraken verbonden zijn - de pijn van het beleid -, nationaal democratisch te worden gelegitimeerd. 


\section{VERDERE VERSTERKING VAN BESTUURLIJKE VERNIEUWING}

In de vorige hoofdstukken heeft de raad een argumentatielijn bepleit die de decompositie, vereenvoudiging en concretisering van het beleid centraal stelt, evenals een inzet om via experimenteren, monitoren en leren verder te komen met het beleid ten aanzien van duurzame ontwikkeling. In plaats van een nieuwe, additioneel op coördinatie gerichte, 'kop' op het beleid te zetten, moet de bestuurlijke vernieuwing die al gaande is, verder worden versterkt. In dit hoofdstuk wil de raad binnen zijn argumentatielijn enkele suggesties aanreiken voor een verdere bestuurlijke operationalisatie van het streven naar duurzame ontwikkeling. Hierbij houdt de raad de onderverdeling uit de adviesaanvraag aan: samenwerking met actoren in de maatschappij (par. 5.1), het bevorderen van samenhang op nationaal niveau (par. 5.2) en internationale samenwerking (par. 5.3). Deze suggesties geven geenszins een volledig palet; over alle onderwerpen valt veel meer te zeggen. Gezien het korte tijdsbestek waarin dit advies geschreven moest worden, heeft de raad zich echter gericht op de grootste problemen. Hieronder worden enkele suggesties gedaan om het bestuurlijke instrumentarium verder te ontwikkelen; het (omvangrijke) al bestaande instrumentarium wordt bekend verondersteld en komt hier niet uitvoerig aan de orde.

\subsection{SAMENWERKING MET ACTOREN IN DE MAATSCHAPPIJ}

Er zijn vier algemene richtingen waarlangs de overheid, voortbouwend op het bestaande instrumentarium en de bestuurlijke vernieuwing die al gaande is, haar beleidsinstrumentarium nog verder kan vernieuwen (Hazeu 200oa). Deze richtingen hebben te maken met: de omgang met burgers en bedrijven (par. 5.1.1), de omgang met milieu- en intermediaire organisaties (par. 5.1.2), de overheid als actor en regisseur (par. 5.1.3) en het belang van beleidsanalyse, informatie en voorlichting (par. 5.1.4). In het verlengde van dit laatste punt wordt apart aandacht geschonken aan de indicatorenontwikkeling waarop het beleid momenteel zwaar inzet (par. 5.1.5).

\subsubsection{DE OMGANG MET BURGERS EN BEDRIJVEN}

In situaties waarin collectieve belangen niet (goed) gerealiseerd kunnen worden omdat private actoren free rider kunnen zijn op de inspanningen van anderen, is publiek handelen noodzakelijk. Dat is de klassieke idee van overheidssturing. Met de groeiende rol van de overheid in de samenleving gedurende de vorige eeuw is gaandeweg echter gebleken dat aan deze klassieke overheidssturing ook nadelen kleven. De overheid moet voor steeds meer zaken verantwoordelijkheid dragen, wordt daarop aangesproken en staat - in een (kennis)samenleving van mondige, goed opgeleide burgers - voor een toenemende legitimatielast bij de beleidsvorming en een toenemende handhavingslast bij de beleidsuitvoering. In economische termen kan hier worden gesproken van (onderschatte) trans- 
actiekosten van overheidshandelen; in bestuurskundige termen van een 'overbelaste overheid' of een 'overvraging van beleid'.

Een strakke sturing van alle processen die voor duurzame ontwikkeling van belang zijn, veronderstelt dat de overheid met behulp van nauwkeurige normen en streng toezicht de private sector tot het gewenste gedrag kan brengen. Deze veronderstelling is niet realistisch. Zij vergt immers een kennis- en een controlepotentieel bij de overheid waarover deze niet beschikt. De veronderstelling is ook ongewenst, omdat het de eigen verantwoordelijkheid van de private sector ten aanzien van duurzame ontwikkeling verengt tot het volgen van de regels van de overheid. Als reactie hierop is in de loop der tijd dan ook gezocht naar meer mogelijkheden voor burgers en bedrijven om zelf meer verantwoordelijkheden te dragen, en hen hiertoe te stimuleren. Dat betekent dat er van private actoren een zekere mate van zelfbinding wordt verwacht: zij leggen zichzelf aan banden bij hun gedragsmogelijkheden, bijvoorbeeld door rekening te willen houden met de negatieve langetermijneffecten van hun gedrag.

In een moderne sturingsopvatting is het nastreven van bijvoorbeeld een duurzame ontwikkeling dan ook geen exclusief publieke taak. Ook los van overheidsvoorschriften of -stimuli leggen bedrijven zich toe op 'maatschappelijk ondernemen' en burgers op 'duurzaam consumeren'. Deze denkrichting sluit ook aan op een specifiek kenmerk van de ecologische duurzaamheidsproblematiek: het langetermijnkarakter ervan impliceert dat de negatieve externe effecten van onduurzaam handelen vaak ver in de toekomst liggen. Burgers en bedrijven worden dus in veel gevallen niet onmiddellijk geconfronteerd met de ecologische gevolgen van hun economisch en maatschappelijk handelen, die bovendien, zoals gezegd, deels onzeker zijn. Tegen deze achtergrond zijn convenanten tussen overheden en private partijen ontwikkeld als beleidsinstrument.

In bovenstaande 'moderne' optiek worden burgers en bedrijven niet alleen opgevat als beleidssubjecten, maar ook gezien als mede-'aanstuurders'; aanstuurders die deels dezelfde doelen hebben en waarmee 'bondjes' te sluiten zijn. Het beleid van de overheid is hierbij gericht op processen van gedragsverandering (transities), oftewel beïnvloeding van de preferenties van actoren. De wijzen waarop dialoog en interactie plaatsvinden tussen beleid en stakeholders, kan gedifferentieerd worden in de tijdsfase van de problematiek: signalering, consultatie, hiërarchisering en besluitvorming. Vooral in de eerste twee fasen kan een maatschappelijke dialoog hierbij een belangrijke toevoeging zijn.

Het zoeken naar en bevorderen van gedeelde opvattingen sluit natuurlijk ook aan bij het Nederlandse cultuurkenmerk van de overlegsamenleving: niet te directief van bovenaf, maar altijd goed praten met elkaar en gericht op het bereiken van consensus. Hoe meer consensus er op voorhand in de beleidsvorming kan worden bereikt, hoe minder transactiekosten (handhavingskosten e.d.) er in de uitvoering gemaakt hoeven te worden. Anderzijds moet bij dergelijke participatieve processen niet de illusie worden gekoesterd dat een volledige consensus (unani- 
miteit) kan worden bereikt, of dat een beleid tot stand komt dat niet kan of zal worden aangevochten (zie par. 3.1). Hier ligt dus een instrument, maar - zoals bij de meeste instrumenten - is de werkzaamheid ervan aan grenzen gebonden.

Uiteraard kleven aan deze 'moderne' verdeling van publieke en private verantwoordelijkheden ook beperkingen. $\mathrm{Zij}$ is niet zozeer een substitutie voor de klassieke overheidssturingsmiddelen maar vooral een correctie en aanvulling daarop. De verdeling kan echter wel consequenties hebben voor de manier waarop wordt omgegaan met en toezicht wordt uitgeoefend op private partijen. Vroeger werd het als ideaal gezien - ook vanuit rechtsstatelijk gezichtspunt - dat de overheid strakke regels stelde en streng toezicht hield op de naleving daarvan. Dit gaf rechtszekerheid: men wist precies waar men aan toe was en de overheid stelde geen onverwachte eisen. De nadelen van deze benadering zijn echter ook duidelijk geworden: er kan een veelheid van, moeilijk naleefbare, gedragsvoorschriften ontstaan die bij de snelheid van nieuwe ontwikkelingen lang niet altijd de meest effectieve zijn om de beoogde doelstelling te bereiken. Bovendien wordt er geen beroep gedaan op de verantwoordelijkheid van private partijen, die vaak over een grote ('lokale') kennis beschikken over de wijze waarop nadelige milieu-effecten kunnen worden voorkomen. Door partijen in de private sector sterker aan te spreken op de behaalde resultaten, en minder op het naleven van gedetailleerde regels, kan de eigen verantwoordelijkheid van private partijen worden geaccentueerd. In dit kader past ook de ontwikkeling dat partijen over een eigen stelsel van kwaliteitszorg beschikken. De controle door de overheid krijgt dan meer het karakter van meta-controle: komen private partijen inderdaad tot eigen stelsels van controle en kwaliteitsborging (Scheltema 2002)? Ook dit onderwerp van de eigen kwaliteitszorg van private partijen leent zich voor het maken van afspraken in convenanten.

Verder vraagt een overheid die vele horizontale contacten onderhoudt met bedrijven, burgers, plaatsbekleders, enzovoort, ook om een enigszins stabiele, betrouwbare en bestendige interne organisatie. Zij moet zelf niet onderwerp zijn van voortdurende reorganisatie (zie ook verder par. 5.2).

Ten slotte is het van belang om hier te benadrukken dat de overheid zich niet rijk moet rekenen aan een na te streven maatschappelijke consensus. Wanneer duurzaamheid als waarde wordt gezien, impliceert dit dat ook andere actoren met die waarde 'werken' en er handen en voeten aan willen geven. Dat gebeurt ook allerwegen: in land- en tuinbouw, bij Shell, Albert Heijn, enzovoort. Deze actoren maken hun eigen afwegingen, vanuit hun eigen doeleinden, omgeving en handelingssituaties. De overheid moet en kan niet de pretentie hebben die afwegingen allemaal in de richting van haar eigen afweging te willen ombuigen. Hooguit kan zij het onderlinge maatschappelijke leervermogen en de informele sociale controle stimuleren (bijv. door informatieverplichtingen) en de kaders daarvoor creëren. 


\subsubsection{DE OMGANG MET MILIEU-EN INTERMEDIAIRE ORGANISATIES}

De tweede richting, de omgang met milieu- en intermediaire organisaties, sluit op het bovenstaande aan. Zo goed en zo kwaad als dat gaat, en soms slechts tijdelijk, zal de consensus moeten worden bereikt door een gezamenlijke noemer te vinden, zoals probleemdefinitie (common concern), begrippenkader, oplossingsrichtingen en dergelijke. Nu de traditionele politieke partijen en de daarop gebaseerde vertegenwoordigingsdemocratie in betekenis afnemen, is het langs die lijn verkregen politieke handelingsvermogen vaak niet voldoende. Om beleidslegitimatie te verwerven, zal de overheid - direct of via intermediaire organisaties zoals de SER of tijdelijke overlegorganen - er daarom steeds vaker toe overgaan om contacten te leggen met single-issue-bewegingen op ecologisch terrein. Inzet hierbij is om te komen tot gedeelde opvattingen over de problemen en de risico's daarbij die aan de orde zijn. Deze organisaties fungeren dan mede als bron van additionele informatie over (de intensiteit van) gepercipieerde problemen. Dit zijn processen van 'zoeken en tasten', waarbij de gewenste uitkomsten niet op voorhand kunnen - en moeten! - worden gedefinieerd. Integendeel. Een 'veil of vagueness' (Gibson and Goodin 1999) kan partijen helpen om bekend te raken met elkaar, te wennen aan de gedachte dat er iets moet gebeuren en de eerste stappen te zetten, die dan mogelijkerwijs later tot resultaten kunnen leiden die niet van tevoren te voorspellen zijn. Dit sluit ook aan op het inzicht van Lindblom (1965) dat partijen het makkelijker eens worden over processen en instrumenten dan over doelstellingen, laat staan ultieme doeleinden. Processen en middelen kunnen immers meer dan één doel dienen, terwijl die verschillende doelen onderling kunnen conflicteren. Bij de moeilijke problemen is het dus zaak deze ambiguïteit te benutten.

De institutionele inbedding van belangen in (corporatistisch) bestuur brengt in het algemeen een aantal voordelen en leereffecten met zich mee (Visser en Hemerijck 1997: 95-96). Deze zijn met name gelegen in een institutionele stabiliteit, langetermijnoriëntaties, het idee dat afspraken moeten worden nagekomen, interorganisatorische coördinatie, een gedeelde waarneming van gemeenschappelijk waargenomen onplezierige feiten en een probleemoplossende stijl van besluitvorming. Uit de sociaal-economische wereld is geleerd dat corporatistische instituties van belangenrepresentatie participatie in de beleidsontwikkeling bevorderen. Bovendien bevorderen zij dat de betrokken organisaties en hun onderhandelaars zich ook oriënteren op de lange termijn. Dergelijke herhaalde, of iteratieve, 'spelen' doen zich voor in de schaduw van de toekomst ("we zien elkaar nog terug”), dragen ertoe bij dat onderling vertrouwen tussen partijen wordt ontwikkeld en dat wordt gezocht naar win-win-uitkomsten: oplossingen waar alle partijen baat bij hebben. Dankzij de institutionele stabiliteit en de daaruit voortvloeiende toegenomen voorspelbaarheid van gedrag, waaronder het vermijden van schadelijke conflicten, ligt de winst van een dergelijke institutionalisering in de besparing van transactiekosten. Het maakt single-issue-bewegingen tot bredere maatschappelijke organisaties. 


\section{Zware institutionalisering ongewenst}

Het zal onmiddellijk duidelijk zijn dat het concept van het sociaal-economische poldermodel maar zeer ten dele kan worden 'geëxporteerd' naar andere velden. Als de win-win-mogelijkheden ontbreken, zullen partijen minder tot 'ruil' bereid zijn. De overheid is dan weer op zichzelf aangewezen, zoals een actuele analyse van het Convenant Glastuinbouw en Milieu, dat naar de resultaten gemeten is mislukt, laat zien (Van de Peppel en Woltjer 2002).

Een dergelijke zware institutionalisering van de contacten van overheden, milieuorganisaties en andere betrokkenen is niet per sé nodig. Anders dan in de sociaal-economische sector, ligt zij zelfs niet erg voor de hand. In een onzekere wereld, waarin risico's en de percepties hiervan snel kunnen veranderen, zullen milieuorganisaties en andere zaakwaarnemers bij voorkeur hun handen slechts beperkt willen binden. Zij kunnen dan immers de steven tijdig wenden als zij daar aanleiding voor zien. Ook vanuit het publieke gezag geredeneerd, is het niet verstandig op een zware institutionalisering in te zetten; tegenover de 'informatiewinst' staat immers dat aan de 'stakes' blokkademacht wordt uitgedeeld. Daarbij komt dat de toedeling van eigendomsrechten in het milieudebat soms onduidelijk is (hebben omwonenden van Schiphol bijvoorbeeld wel of geen recht op vrijwaring van geluidshinder?). De internalisering van externe effecten kan hierdoor tot allerlei belangentegenstellingen leiden die via een discussie tussen de stakeholders niet zijn op te lossen. Stakeholders kunnen in zulke situaties opkomen voor hun eigen belangen terwijl zij voorbijgaan aan de belangen van anderen die wél, of ook, een eigendomsrecht hebben. Het is van belang dit goed voor ogen te hebben aangezien het succes van het (economische) poldermodel sommigen ertoe brengt om ook een 'groen poldermodel' te bepleiten. Zo'n groen poldermodel problematiseert echter te weinig dat er ook nadelen en 'kosten' (in ruime zin) verbonden zijn aan een zware institutionalisering van overleg. Ten tweede ziet het over het hoofd dat het sociaal-economische overlegmodel is gebaseerd op de mogelijkheid dat zich een 'win-win'-situatie voordoet. Deze situatie levert de partijen die zich in een geïnstitutionaliseerd overleg binden, bepaalde (welvaartseconomische) voordelen op die potentieel de (welvaartseconomische) kosten kunnen overtreffen. Anders gezegd: werkgevers en werknemers hebben een gezamenlijk voordeel bij goede arbeidsverhoudingen; dat is de common good, de winst die in het 'spel' zit. Daarom zijn zij bereid te 'investeren': iets 'weg geven' om er meer 'uit te krijgen'.

Bij de verdere ontwikkelingen wat betreft duurzaamheid zijn de win-win-mogelijkheden echter beperkt; het 'laaghangend fruit' is immers als eerste geplukt. De moeilijke problemen vragen bijna steeds keuzes tussen ecologische versus economische waarden. Het denkkader van de Verkenning impliceert min of meer dat zaakwaarnemers van ecologische waarden vaste posities zouden moeten krijgen in bijvoorbeeld de plenaire SER. Anders dan bij de huidige lichte institutionalisering (constructieve deelname aan relevante commissies, inclusief de mogelijkheden voor milieuorganisaties om onderwerpen te agenderen, en na verloop van tijd te evalueren) is het gevaar van een dergelijke zware institutionalisering dat 
zaakwaarnemers van ecologische waarden niet op het relevante niveau een positie innemen en niet tot 'ruilen' genoopt zijn. In dat geval kunnen mogelijke keuzes en substituties op voorhand uitgesloten worden omdat ze door de wijze van institutionalisering niet eens in zicht komen. De raad acht dit ongewenst. Het gaat er immers om zichtbaar te maken hoeveel het kost om bijvoorbeeld de korenwolf, de noordse woelmuis (Microtus oeconomicus) of de zeehond in Nederland te behouden. Vervolgens is de vraag of we dat bedrag daar ook voor over hebben. Deze schaduwwaarde is immers ook het bedrag dat potentieel beschikbaar is om andere natuur te 'maken', mochten we daarvoor kiezen.

Een zware institutionalisering is dus niet gewenst; een lichte wél. Die kan helpen de consensusvorming in het milieubeleid te bevorderen. Daarbij dient ook de inbreng van wetenschappelijke kennis een belangrijke rol te spelen, net zo als in het sociaal-economische SER-model (via de kroonleden). Die inbreng kan bijdragen aan een helder inzicht in de verschillende belangen en de ruilwaarden die ten grondslag liggen aan de afweging van die belangen. Een zo goed mogelijke internalisering van de externe effecten, gegeven de eigendomsrechten, vormt daarbij het uitgangspunt.

\subsubsection{OVERHEID ALS ACTOR ÉN REGISSEUR}

Bij processturing hoort dat de overheid 'zich wat kleiner maakt' en ook plaats maakt voor andere actoren. Dat is kenmerkend voor de besturingsconcepten die passen bij een multi-actorsamenleving. In de (nieuwe) institutionele economie spreekt men van plural principals: er is niet langer één principaal die doelen, wensen en opdrachten articuleert, maar er zijn er meerdere die processen aansturen (Hazeu 200o: 98 e.v.). Men laat zo verschillende opvattingen toe over wat wenselijk gedrag is. Toch mag een constellatie van meerdere actoren er niet toe leiden dat de verschillende actoren eindeloos tegen elkaar in kunnen werken en elkaar gevangen houden in een prisoner's dilemma. Zo'n constellatie zal moeten functioneren als een mechanisme voor consensusvorming. Processturing is erop gericht om punten van overeenstemming te vinden. Inmiddels opgedane ervaringen met wetenschappelijke en maatschappelijke dialoogprocessen (zoals rond klimaat en grootschalige luchtverontreiniging) leren ook dat deze processen (mits de verschillende gezichtspunten redelijk kunnen worden weergegeven) de acceptatie van een modelbenadering kunnen vergemakkelijken. Maas (2000) concludeert dat modellen op deze manier een rol kunnen spelen in de gezamenlijke zoektocht naar duurzame ontwikkeling. Duurzame ontwikkeling wordt dan een participatief leerproces van beleidsmakers, deskundigen en belanghebbenden.

In een overlegdemocratie zal processturing verder moeten helpen om vast te stellen wat de belangrijke vraagstukken zijn. De overheid heeft hierbij een taak met betrekking tot de regie en de spelregels. Bij sociale dilemma's die anderszins niet tot een oplossing komen, zal de politiek echter wél het laatste woord moeten houden. Het is dus niet het primaat, maar het 'ultimaat' van de politiek dat van belang is. De overheid blijft de actor die de regie kan en moet voeren over de 
bevoegdheden en de verdeling daarvan in een beleidsarena; geen enkele andere actor kan dit immers. De overheid als actor moet bovendien onverminderd bindende beslissingen (kunnen) nemen, tussen partijen gemaakte afspraken al dan niet 'algemeen verbindend verklaren', alsmede randvoorwaarden stellen, bijvoorbeeld ten aanzien van de toelaatbare emissieniveaus. Aan de kant van burgers en bedrijven geldt dat de behoefte aan goed bestuur (good governance) zeker niet minder zal worden in een complexer wordende samenleving. Ook zal bestuurlijke energie onverminderd nodig blijven om synergie in het handelen van de verschillende overheden te bevorderen. In paragraaf 5.3 wordt deze gedachte ook uitgewerkt in de richting van verdere internationale bewerktuiging van het duurzaamheidsbeleid.

\subsubsection{HET BELANG VAN INFORMATIE, VOORLICHTING EN BELEIDSANALYSE}

Dat de toegang tot betrouwbare kennis en informatie een belangrijk element vormt van modern burgerschap, is algemeen geaccepteerd. De overheid zal niet alleen zelf informatie en voorlichting moeten geven, maar meer algemeen de toegang tot informatie voor burgers moeten garanderen. Burgers drijven in hun ecologisch handelen immers sterk op percepties van ecologische kwaliteit. Voor zover beschikbaar, dient wetenschappelijke informatie over ecologische criteria, risico's en vergelijking van risico's toegankelijk te zijn en uitgedragen te worden. De ontwikkeling van onafhankelijke instituties die de kwaliteit keuren van producten en dergelijke, zoals de huidige Nederlandse Voedsel en Waren Autoriteit in oprichting, kan daaraan bijdragen.

Zoals al gesteld, moet de overheid ook in het duurzaamheidsbeleid normatieve afwegingen en keuzes maken, deze legitimeren en actief uitdragen. Hierbij moet zij zich kunnen baseren op gedegen beleidsanalytische studies en onafhankelijke instituties die dergelijke studies kunnen aanreiken (zoals het RIVM en de andere planbureaus). In kennistermen uitgedrukt: de beleidsanalyse draagt eraan bij dat er geen onoverbrugbaar verschil ontstaat tussen gedeelde kennis en betrouwbare kennis (March 1999).

In het kader van de behoefte aan informatie en voorlichting speelt verder de maatschappelijke verantwoordelijkheid van niet-statelijke actoren. Hierbij horen ook vormen van verantwoording. Dit betekent dat informatie moet worden verstrekt over de wijze waarop actoren met het duurzaamheidsaspect zijn omgegaan. Deze informatie moet zoveel mogelijk het karakter hebben van openbare verantwoording. Zij moet in beginsel bruikbaar zijn voor zowel de overheid, die immers controle moet uitoefenen, als de samenleving: reacties van consumenten en organisaties. Voor deze verantwoording geldt, evenals voor de financiële verantwoording, dat externe verificatie nodig is (vergelijk de ontwikkeling van milieuverslaggeving via accountantscontrole).

Ten slotte krijgt het belang van kennis, informatie en analyse ook vorm in een zoektocht naar bruikbare indicatoren. Omdat dit onderwerp momenteel veel 
belangstelling krijgt, wordt hieraan in de volgende subparagraaf apart aandacht geschonken.

\subsubsection{INDICATOREN}

In het duurzaamheidsbeleid is de behoefte ontstaan aan indicatoren die zichtbaar kunnen maken of de ontwikkelingen in een duurzame richting gaan. Bijlage 2 van de Verkenning bevat, bij wijze van aanzet, een set van in totaal 36 duurzaamheidsindicatoren in Nederland. De planbureaus (m.n. het RIVM) is gevraagd te helpen bij het opstellen van een definitievere set van indicatoren. De SER gaat in zijn advies over duurzame ontwikkeling ook in op dit onderwerp (SER 2OO2). In dit advies van de WRR over bestuurlijke vernieuwing is het niet opportuun om deze set van indicatoren uitputtend te bespreken. Wél wordt er een aantal methodologische opmerkingen over gemaakt.

In de eerste plaats is het van belang de rationale van indicatoren goed voor ogen te hebben. Met andere woorden: wat moeten zij kunnen 'doen' en uitdrukken; in welke context moeten ze functioneren? De criteria daarvoor moeten helder zijn, wil de eerste aanzet uit de Verkenning op een hoger plan gebracht kunnen worden.

Het centrale gezichtspunt van dit WRR-rapport is dat het beleid dat nu wordt samengenomen onder 'duurzame ontwikkeling', vraagt om decompositie. Alleen op die manier kan worden gekomen tot concrete beleidsaanpakken, kunnen de noodzakelijke politieke afwegingen transparanter worden gemaakt, en kunnen leerprocessen en terugkoppelingen in het beleid worden bevorderd. Volgens de raad spelen bij de behoefte aan en ontwikkeling van indicatoren drie vragen. Gaat het om:

1. milieu-indicatoren of indicatoren voor duurzame ontwikkeling?

2. samengestelde of enkelvoudige indicatoren?

3. beleidsindicatoren of toestandsindicatoren (ook wel druk- of effectindicatoren)?

\section{Milieu-indicatoren of indicatoren voor duurzame ontwikkeling}

In dit advies is ervoor gepleit het beleid te concentreren op duurzaamheid in zijn betekenis van ecologische waarden en de afwegingen die van daaruit worden gemaakt. Het is al ingewikkeld genoeg om dat handen en voeten te geven en te voorkomen dat 'beleidsstapelingen' de actoren in de samenleving verlammen in plaats van hen te mobiliseren. Duurzame ontwikkeling heeft dus betrekking op een afwegingskader (van ecologische, economische en sociaal-culturele waarden); daarvoor is als zodanig geen indicator te maken. Te ontwikkelen indicatoren moeten daarom milieuwaarden indiceren - zoals waterkwaliteit, biodiversiteit of klimaatverandering - of activiteiten die voor die milieuwaarden relevant zijn, zoals $\mathrm{CO}_{2}$-uitstoot (vgl. bijv. Adriaanse 1993). Indicatoren zoals 'inkomensverdeling', 'slachtoffers van criminaliteit', 'arbeidsparticipatie van vrouwen', 'arbeidsongeschiktheid', 'asielaanvragen', 'opleiding wo/Hво' of 'uitgaven aan R\&D' geven voor de betreffende terreinen relevante informatie, maar zijn stuk 
voor stuk 'te ver van huis' om te kunnen dienen als relevante indicator voor duurzaamheid vanuit het ecologisch perspectief.

Deze breedheid aan indicatoren suggereert bovendien dat duurzaamheid ermee is gediend wanneer zich op al deze gebieden positieve ontwikkelingen voordoen. Het gaat er echter om zichtbaar te maken dat ecologische duurzaamheid als waarde vaak op gespannen voet staat met economische en sociaal-culturele waarden. Wanneer deze spanning zich voordoet, kan het, vanuit oogpunt van duurzaamheid gezien, zo zijn dat een verbetering op een milieu-indicator een verslechtering impliceert op andere (economische en sociaal-culturele) indicatoren.

\section{Enkelvoudige of samengestelde indicatoren}

In de tweede plaats kan er onderscheid worden gemaakt tussen enkelvoudige en samengestelde indicatoren. Atkinson et al. (2002) stellen enkele methodologische eisen aan het zinvol gebruik van deze twee typen.

Criteria voor enkelvoudige indicatoren:

- Een indicator moet de essentie van het probleem weergeven en een geaccepteerde normatieve interpretatie hebben.

- Een indicator moet robuust zijn en statistisch valide.

- Een indicator moet beleidseffecten kunnen laten zien, maar mag niet manipuleerbaar zijn.

- Als het gaat om vergelijkingen tussen landen, moeten er ook vergelijkbare situaties achter de indicator schuil gaan.

- Een indicator moet reviseerbaar zijn als veranderingen in data en achterliggende concepten daar aanleiding voor geven.

- Het meten van een indicator moet relatief eenvoudig zijn en mag niet te veel kosten met zich meebrengen.

Aanvullende criteria voor samengestelde indicatoren zijn:

- De indicator moet gebaseerd zijn op een goede balans tussen de verschillende dimensies.

- De gewichten van de verschillende dimensies mogen niet te ver uiteen lopen (zou bijvoorbeeld één dimensie een zeer groot gewicht in de schaal leggen, dan is het beter te kiezen voor een enkelvoudige indicator).

- De indicator moet zo transparant mogelijk zijn en dient idealiter door burgers begrepen te kunnen worden.

Vooral in de internationale fora wordt relatief veel gebruik gemaakt van samengestelde indicatoren. Vergelijkingen door middel van lange lijsten van enkelvoudige indicatoren geven vaak een diffuus beeld en zijn hierdoor minder 'behapbaar'. Om elkaar te stimuleren - het gaat immers om meer dan naming and shaming - is er daarom vaak een voorkeur om aan de hand van samengestelde indicatoren kort en snel vast te stellen wie het goed doet en wie minder. Niet alleen bij het milieu, maar bijvoorbeeld ook bij welzijn, gezondheid of het vestigingsklimaat van bedrijven worden daartoe samengestelde indicatoren ontwikkeld waarin relevante aspecten en componenten worden samengenomen, zodat vervolgens de score kan worden afgelezen. 
Bij samengestelde indicatoren moet worden voorkomen dat zij nietszeggende grootheden zijn die los staan van een context: waar hebben we het eigenlijk over en wat zouden we moeten doen? Een tweede gevaar houdt hiermee verband: bij dit soort samengestelde indicatoren worden - soms impliciet - deelindicatoren gekozen en gewogen zonder dat deze (als zodanig, en met hun relatieve gewicht) zichtbaar worden. Zo heeft Nederland een heel goed vestigingsklimaat, maar kan aan de indicator niet worden afgelezen wat de factoren zijn die het 'doen' (lage belastingen?; lage prijzen?; lage criminaliteit?) en dus ook niet waar vergelijkenderwijs wat moet gebeuren of waar nog 'winst' te maken is.

Ook een 'indicator natuurwaarde' telt een aantal kwantitatieve en kwalitatieve aspecten bij elkaar op, zonder dat het hoe en wat zichtbaar wordt. In de Verkenning wordt een Duurzaam (of 'groen') Nationaal Inkomen (DNI) als indicator geopperd, maar deze gaat hier eveneens onder gebukt. In een DNI worden de waarde (of de waardeontwikkeling in de tijd) van de materiële productie en het waardeverlies door milieuschade in één eenheid opgenomen (eventueel nog verder uit te breiden met een sociale-waardecomponent). De afwegingen tussen verschillende waarden wordt als het ware in technische coëfficiënten 'gestold'. Er zijn twee hoofdbezwaren tegen een DNI (Den Butter, Hofkes en Verbruggen 1994). In de eerste plaats maken de grote onzekerheid en langetermijneffecten het vrijwel ondoenlijk om milieudegradatie in een monetaire waarde uit te drukken; er worden dan 'wild guesses' ingebracht die van een andere orde zijn en die contrasteren met de behoedzaamheid en ervaring waarmee de bekende nationaalinkomencomponenten worden vastgesteld. In de tweede plaats is de waardering van het milieu in de tijd veranderlijk en vergt zij een keuze die altijd politiek van aard is. In plaats van dat de door beleidsmakers te maken afwegingen door technische coëfficiënten worden overgenomen, is het informatiever om beide componenten - waarde van de materiële productie en kwaliteit van het milieu - afzonderlijk te laten zien. Dat geeft een beter zicht op de ontwikkelingen en op de afweging die - expliciet of impliciet - tussen deze twee (of meer) aspecten of doelen is, wordt of moet worden gemaakt.

Op zich is het mogelijk om via een berekening met een toegepast algemeen-evenwichtsmodel aan te geven wat het 'nationaal inkomen' zou zijn onder strikte ecologische randvoorwaarden. Dit gebeurt bij de berekening van het 'Duurzaam Nationaal Inkomen volgens de methodiek van Hueting' (zie Verbruggen 20oo). Deze berekening gaat ervan uit dat de ecologische randvoorwaarden de grenzen zijn waarnaar het gebruik van het milieu dient terug te keren om een duurzaam ecologisch evenwicht te bereiken. In die redenering van ecologische duurzaamheid bestaat er dus geen ruimte om een verder milieugebruik en andere aspecten van de welvaart tegen elkaar af te wegen. Er zitten vele arbitraire elementen in dit soort berekeningen. Bovendien bestaat er een grote wetenschappelijke onzekerheid over de ondergrenzen die dan als ecologische randvoorwaarden zouden moeten gelden. In het voorafgaande heeft de raad dan ook beargumenteerd dat ruilmogelijkheden tussen verschillende bronnen van welvaart in beginsel niet volledig moeten worden uitgesloten. 


\section{Beleidsindicatoren of toestandsindicatoren}

Het is van belang het onderscheid tussen deze soorten indicatoren scherp te maken, omdat niet iedere toestand (bijv. van een milieuaspect) geheel of volledig door het beleid wordt veroorzaakt of beïnvloed - hoewel beleidsmakers dat soms wel willen (doen) geloven. Er zijn zelfs toestanden die als beleidsimmuun of beleidsresistent kunnen worden aangemerkt. Wél is er zowel behoefte aan concrete informatie over de toestand van milieuaspecten, als aan de effectiviteit van beleidsprogramma's. Relevante toestandsindicatoren zeggen bijvoorbeeld iets over de soortenrijkdom of over de mate van vermesting, verdroging of uitstoot van broeikasgassen. Bij beleidsindicatoren gaat het erom zo goed mogelijk kwantitatief te kunnen vangen wat er met een bepaald (juridisch, financieel of ander) instrument wordt nagestreefd, zodat de effectiviteit van het beleid kan worden beoordeeld. Dit is een problematiek die momenteel bijvoorbeeld aan de orde is in het kader van de VBTB-systematiek ('Van Beleidsbegroting tot Beleidsverantwoording'). Daar blijkt ook dat het vaak al lastig genoeg is een passende indicator te vinden. Veel instrumenten zijn immers gericht op meerdere doelstellingen en veel doelstellingen worden door meerdere instrumenten (en ook nog eens door exogene ontwikkelingen) beïnvloed.

\subsection{BEVORDEREN VAN SAMENHANG OP NATIONAAL NIVEAU}

Kabinetsformaties zijn in Nederland bij uitstek het moment waarop de bestaande departementale indeling aan de orde komt, evenals de onvermijdelijke coördinatieproblemen die iedere organisatorische verkokering met zich mee brengt. Verder bieden zij een nieuwe regering een uitgelezen mogelijkheid om specifieke accenten te plaatsen bij onderwerpen waaraan men graag direct zichtbaar meer aandacht wil geven. In dit verband kan hier de vraag worden gesteld of er een aparte (coördinerend) minister voor Duurzame Ontwikkeling moet komen en waar deze gepositioneerd zou moeten worden. Nu is de minister van Volkshuisvesting, Ruimtelijke Ordening en Milieubeheer (VROM) tevens coördinerend minister voor Duurzame Ontwikkeling.

Uit de omvattende coördinatieoptiek die uit de Verkenning spreekt, vloeit logischerwijs de gedachte voort om de minister-president tevens tot coördinerend minister voor Duurzame Ontwikkeling te maken. In het verlengde van de lijn die de raad in dit advies heeft uiteengezet, wijst de raad deze gedachte echter van de hand. In hoofdstuk 2 is er immers voor gepleit om het begrip 'duurzaamheid' te ontwarren en er geen sjablonenbegrip van te maken waaronder alle mogelijke beleidsterreinen met een intergenerationeel aspect bijeen worden gebracht. Duurzame ontwikkeling dient naar de opvatting van de raad te worden gehanteerd in de engere, maar mede daardoor meer operationele, betekenis van: beleid gericht op ecologische waarden. Het gaat dan vooral over onderwerpen als: klimaat, water, biodiversiteit, en (wereld)bevolking.

Bij de organisatie van duurzame ontwikkeling op ministerieel en departementaal niveau pleit de raad er daarom voor om steeds de beleidsproblemen als uitgangs- 
punt te nemen. Hiervoor bestaat ook veel expertiseopbouw bij het ministerie van Volkshuisvesting, Ruimtelijke Ordening en Milieubeheer (milieu), maar ook bij de ministeries van Buitenlandse Zaken (ontwikkelingssamenwerking), Verkeer en Waterstaat (water), Landbouw, Natuurbeheer en Visserij, Economische Zaken (energiebeleid, duurzaam ondernemen, wetgeving milieuverslaglegging door bedrijven) en op tal van plaatsen elders. In de praktijk zal de minister van VROM vaak het voortouw hebben in de coördinatie van het beleid. In andere gevallen echter niet: neem bijvoorbeeld de relatie met ontwikkelingslanden, en het aanbrengen van stimuli om daar duurzame ontwikkeling te bevorderen. In dat geval zal de minister voor Ontwikkelingssamenwerking het voortouw hebben. Bij de waterproblematiek zal de eerste inhoudelijke en coördinerende verantwoordelijkheid bij de minister van Verkeer en Waterstaat moeten liggen en als het gaat om het energiebeleid of het bevorderen van duurzaam ondernemen in de industrieen dienstensectoren, is het de minister van Economische Zaken die het voortouw neemt. Gaat het om het beleid ten aanzien van het duurzaam ondernemen in de landbouw, dan ligt de coördinatie in handen van de minister van Landbouw, Natuurbehoud en Visserij, en bij de 'vergroening' van het belastingstelsel is het de minister van Financiën die de coördinerende rol op zich neemt. Enzovoort. De minister van Algemene Zaken heeft een algemene coördinerende rol ten aanzien van alle regeringsbeleid. Hierbij hoort ook dat hij initiatieven ontplooit als de andere departementen in hun coördinatie tekort schieten.

In het algemeen gaat het erom te bereiken dat op de verschillende relevante beleidsterreinen duurzaamheid een rol speelt in de afwegingen die worden gemaakt. Dat lukt in het algemeen beter als niet één minister bij uitstek de verantwoordelijkheid voor duurzame ontwikkeling krijgt toebedeeld. Dat zou eerder averechts kunnen werken. In de ogen van andere ministers/departementen staat dat mogelijk een verdere internalisering van duurzaamheidsafwegingen in de weg; het is dan immers al de verantwoordelijkheid van iemand anders.

\section{$5 \cdot 3$ INTERNATIONALE BEWERKTUIGING}

De ontwikkeling van nieuwe 'zachte' instrumenten is ook in het kader van een internationale samenwerking op milieuterrein van groot belang. Dergelijke instrumenten spelen vooral een aanvullende rol waar landen, aan het begin van een internationale beleidsvormingsfase, met elkaar in gesprek moeten worden gebracht. In de laatste jaren hebben belangrijke ontwikkelingen in deze richting binnen en buiten de EU plaatsgevonden. In de EU is de laatste jaren de Open Coördinatie Methode (OCM) opgekomen, niet ter vervanging van maar ter aanvulling op de bestaande top-down-benadering. Omdat het voorbeeld van ocm past in het concept om beleidsontwikkeling via 'leren' en 'monitoren' verder te brengen (zoals in de vorige paragrafen al bepleit op nationaal niveau), is het zinvol hier wat verder op in te gaan. Uiteraard is OcM geen panacee. Bovendien zijn in het milieubeleid van de EU in de loop der tijd al veel richtlijnen tot stand gebracht. 
Deze Open Coördinatie Methode erkent dat bepaalde problemen en de aanpak ervan contextueel bepaald zijn. Zij staat ook in het licht van het geleidelijk populairder worden van het doel- in plaats van middelenbeleid en past in de opvattingen over het subsidiariteitsbeginsel. Ook dit is te bestempelen als een vorm van bestuurlijke vernieuwing die zich al aan het ontwikkelen is. Zij maakt op de betreffende gebieden leergedrag mogelijk, maar vormt als zodanig zeker niet het hele instrumentele spectrum. OCM is hooguit een belangrijke aanvullende component daarop.

Hiermee is ook aangegeven dat een 'zacht' beleidsinstrumentarium niet volstaat. Een zacht beleidsinstrumentarium is nodig en mobiliserend in de agenderingsfase, maar moet gevolgd worden door vormen van institutionalisering en verankering: de altijd aanwezige schaduw van regulering. In dit verband is het ook internationaal een belangrijke voorwaarde dat duurzame ontwikkeling niet over alles, en alles tegelijk gaat, maar over de aspecten van ecologische duurzaamheid die het meest problematisch zijn. Er moet dus een duidelijke focus worden vastgesteld, willen vorderingen controleerbaar zijn. Voor de internationale afspraken die hierover moeten worden gemaakt, is het noodzakelijk aanspreekbare, betrouwbare en realistische indicatoren te ontwikkelen. Verder moeten er onafhankelijke inspectie-instituties (m.n. onder de vlag van de vN) zijn, of komen, die hierover openbare rapportages uitbrengen.

\section{De Europese Unie en de Open Coördinatie Methode}

De besluitvorming in de Europese context heeft een ander karakter dan de nationale besluitvorming. Het beleid wordt in de EU eerst vastgesteld met betrokkenheid van de nationale overheden en moet vervolgens worden uitgevoerd door die nationale overheden? Hieruit kunnen enkele interessante vragen worden afgeleid ten aanzien van deze besluitvormingsconstellatie: op welke manier zijn de nationale overheden bij de totstandkoming van het EU-beleid betrokken, en op welke manier worden kennis en expertise ingezet op Europees niveau. Zo bestaan er tussen de lidstaten van de Europese Unie, die alle in toenemende mate gehoor moeten geven aan Europese regelgeving, grote verschillen in de institutionele capaciteiten en de stijlen van beleidsontwikkeling. Lukt het om blokkades te voorkomen ten aanzien van de EU-besluitvorming die het gevolg kunnen zijn van de grote mate van institutionele diversiteiten? En hoe gaat men hierbij te werk? Hoe, en in welke mate wordt rekening gehouden met het belang van de haalbaarheid en uitvoerbaarheid van het EU-beleid op nationaal niveau? En welke marges behouden de nationale overheden om bij de uitwerking van de Europese regels een zelfstandig beleid te voeren?

Gezien als bestuurlijk experiment is de Europese Unie wellicht qua omvang enigszins vergelijkbaar met het bestuurlijke experiment om wereldwijd tot (een grotere) duurzaamheid te komen. Onder andere als gevolg van de verdere schaalvergroting van de Unie, zijn de laatste jaren ook steeds meer 'zachte' interventie-instrumenten ontwikkeld. De belangrijkste institutionele innovatie in dit opzicht is de ontwikkeling van de zogeheten Open Coördinatie Methode (zie ook hierboven). 
OCM is in principe een benadering van 'management by objectives', waarbij de Europese instituties richtsnoeren ontwerpen en de implementatie hiervan monitoren door middel van een duidelijke procedure. Deze procedure bestaat uit de volgende stappen:

- het stellen van een diagnose van een gemeenschappelijk probleem, gebaseerd op de input vanuit de gemeenschappen op verscheidene niveaus;

- het stellen van prioriteiten voor de gehele Unie en de 'politieke erkenning' van deze prioriteiten op het hoogste institutionele niveau (Europese Raden);

- de identificatie van good-practices en relevante indicatoren voor te bereiken doelstellingen;

- betrokkenheid bij de nationale beleidssystemen door nationale actieplannen te ontwikkelen en specifieke nationale doeleinden te stellen;

- het observeren van het proces en de evaluatie van het beleid door middel van vergelijkend onderzoek;

- het doen van aanbevelingen.

Centraal in de lichte, flexibele en open structuur van осм is de formulering van gemeenschappelijke richtsnoeren en de identificatie van relevante indicatoren voor de te bereiken doelstellingen. Hiernaast zijn het monitoren van prestaties, de uitwisseling en benchmarking van 'good practices', en peer review, belangrijke ingrediënten in het kader van iteratieve, meerjarige cycli van beleidsontwikkeling. Door nationale beleidsmakers ertoe te verplichten informatie systematisch en continu te delen, door het eigen nationale beleid bloot te stellen aan kritiek in het licht van de prestaties (ook van anderen), en om vervolgens staand beleid te herijken in het licht van comparatieve prestaties en ervaringen, genereert OCM een mechanisme van institutionele innovatie. Door het herhalen van procedures begint zich gaandeweg een zekere coördinatiegezindheid en collectieve doelgerichtheid te ontwikkelen onder de relevante supranationale, nationale, subnationale, statelijke en niet-statelijke actoren in de verschillende beleidsterreinen waarop de EU actief is, maar niet altijd helder gedefinieerde competenties bezit. Doordat de implementatie van de richtsnoeren die op Europees niveau ontwikkeld zijn een decentraal karakter heeft, en de nationale ambtelijke apparaten die over een eigen beleidsruimte en politieke legitimiteit beschikken, bij de ontwikkeling van die richtsnoeren betrokken zijn, kunnen ook de nationale beleidsstructuren en -stijlen in termen van doeltreffendheid en doelmatigheid worden verbeterd.

De institutionele vernieuwing van OCM is het meest geschikt voor die problemen die op internationaal niveau worden erkend als vraagstukken van gemeenschappelijk belang. Doordat deze problemen onder condities staan van de grote institutionele diversiteit tussen de participerende lidstaten, kunnen zij niet worden benaderd en opgelost met gemeenschappelijke oplossingen die altijd passen ('one size fits all'). Om praktijken van elders op succesvolle wijze over te nemen is specifieke aandacht nodig voor de nationale en lokale verschillen in de institutionele vormgeving. Dit beperkt de mogelijkheden om 'good practices' direct uit andere nationale stelsels over te nemen. Wil erkend 'goed beleid' succesvol kunnen 
worden geïmplementeerd, dan moet dit worden aangepast aan de lokale institutionele en beleidsinhoudelijke omstandigheden.

OCM veronderstelt voorts een vorm van 'contextualised benchmarking' (Visser en Hemerijck 2001). Deze vorm is gebaseerd op een nauwkeurige analyse van de institutionele omgeving van waaruit bepaalde beleidsoplossingen zijn ontsproten, als ook de lokale condities van implementatie elders. Dit staat tegenover vormen van 'decontextualised benchmarking' zoals die worden gebezigd door internationale organisaties als de OECD, de Wereldbank en het IMF, die veeleer zijn gebaseerd op de generalisatie van gestandaardiseerde, one size fits all modellen van 'best practice'. Het verschil tussen OCM binnen de EU en OECD-benchmarking is dat de OECD-procedure sterk gecentraliseerd is, in hoge mate technocratisch en gelegitimeerd in termen van een dominant wetenschappelijk gedachtegoed. Dit maakt het voor beleidsmakers gemakkelijk om onaardige boodschappen uit Parijs te negeren. In tegenstelling tot deze vorm van 'decontextualised benchmarking', is OCM veel meer een gedecentraliseerde procedure, die erop is gericht een dialoog te ontwikkelen tussen experts en beleidsmakers op supranationaal en internationaal niveau. Van belang daarbij is dat beleidsmakers zelf deelnemen aan de peer review monitoring en dit niet uitbesteden aan zogenaamd onafhankelijke organisaties. Dit maakt het moeilijker om kritiek volledig te negeren. Bovendien bestaat bij beperkte vooruitgang altijd de mogelijkheid van regulering. Deze schaduw van toekomstige regulering bevordert de druk tot de ontwikkeling van vrijwillig overeengekomen compromissen.

Op dit moment functioneert OcM met name in complexe, institutioneel sterk heterogene en politiek gevoelige, beleidsterreinen zoals het werkgelegenheidsbeleid en het sociaal beleid. Het experimentele proces van internationaal beleidsleren kan op zijn beurt bijdragen aan de ontwikkeling van geheel nieuwe 'good practices'. De aanpassing van deze praktijken aan lokale contexten elders kan een voorwaarde vormen voor een verdere internationale diffusie. Hiermee wordt derhalve een cyclus van imitatie en innovatie ingesteld die participanten dichter bij elkaar kan brengen, zonder dat dit erin zou moeten uitmonden dat in een internationale gemeenschap een volledige convergentie plaats vindt van beleid tussen landen.

Wanneer dit soort instrumenten ook meer in het verdere duurzaamheidsbeleid wordt ingebracht, kunnen ze 'meeliften' met de publieke sympathie en deze ook verder versterken. Dit is ook een voorwaarde voor succes. De overheid is dan niet alleen boeman en controleur, maar bedrijven en burgers/consumenten nemen ook zelf verantwoordelijkheid en zij nemen zichzelf en elkaar de maat. Het zachte instrumentarium van OCM voegt hiermee iets toe aan het traditionele Europese instrumentarium, in de zin dat het de blokkades kan vermijden waarmee die traditionele instrumenten (richtlijnen) te maken hebben.

Uiteraard bestaan er ook de nodige vragen. Bijvoorbeeld: hoe werken deze zachte, open coördinatiemethoden in de afwezigheid van bindende sancties, en hoe 
productief zijn zij nu precies? Hoe doeltreffend en doelmatig zijn ze bij het bereiken van gemeenschappelijke doelen? Waaruit bestaat hun bijdrage aan internationaal beleidsleren? Hoe transparant en open is OсM ten aanzien van niet-statelijke maatschappelijke organisaties? En wat is hun effect op de beleidsuitvoering op lagere subnationale en sectorale lagen van bestuur?

Een belangrijk verschilpunt tussen de toepassing van осM op sociaal-economisch gebied en in het milieudomein is bovendien dat, voor zover de milieuproblemen op wereldschaal spelen (zoals de klimaatproblematiek), beleidsoplossingen (of het nalaten daarvan) in het ene land een veel grotere invloed hebben op andere landen dan het geval is in het sociaal-economisch domein. Anders gezegd: de doorsijpeleffecten, en daarmee de externe effecten van het nationaal milieubeleid, zijn in deze gevallen van mondiale problemen veel groter dan die van het sociaal-economisch beleid. Een OCM-achtige benadering kan dus een eerste stap in de gewenste richting betekenen, maar uiteindelijk zullen er ook hardere afspraken met geloofwaardige sanctiemechanismen nodig zijn om een meer duurzame ontwikkeling op mondiale schaal te kunnen bereiken.

\section{Internationale afspraken en bestuurlijke vernieuwing buiten de EU}

Ook ten aanzien van de internationale context buiten de EU valt er de laatste jaren een verschuiving te constateren naar 'neo-voluntaristische regelgeving': het gebruik van niet-bindende aanbevelingen in plaats van bindende richtlijnen. Het vrijwillige karakter van internationale afspraken is groter dan de OCM-richtsnoeren in het kader van de Europese Unie. De erkenning van gemeenschappelijke problemen opent de mogelijkheid om veelbelovende oplossingen en 'good practices' door internationale vergelijkingen te identificeren, niet alleen binnen de Europese Unie maar in potentie ook daarbuiten.

Bij duurzame ontwikkeling vanuit ecologisch perspectief gaat het echter om een aantal zeer moeilijk aan te pakken problemen, waarbij de normatieve opvattingen van de betrokkenen bovendien sterk kunnen verschillen. Hoe komen in die constellatie internationale afspraken tot stand die aanvaardbaar, haalbaar en werkbaar zijn? In hoeverre kan worden voorkomen dat cognitieve onzekerheid over causale verbanden meer gepolitiseerd wordt dan nodig en wenselijk is, en hiermee een blokkade opwerpt bij de besluitvorming? En op welke manier kan - ook via het internationale recht - zorg worden gedragen voor een goede naleving, uitvoering en handhaving van internationale afspraken?

Meer specifiek is de vraag aan de orde hoe het internationale duurzaamheidsbeleid zich verder moet ontwikkelen na de conferentie van Johannesburg van eind augustus 2002. Het zal duidelijk zijn dat niet kan worden volstaan met afspraken om op een volgende wereldconferentie over tien jaar weer 180 documenten van 18o landen op te stellen en aan elkaar voor te leggen. Het zal er nu om moeten gaan de problematiek van besluitvorming - die kan leiden tot free riding en parasitair gedrag - in een grote groep terug te brengen tot een verzameling kleinere groepen, waarin wél voldoende sociale controle op elkaar kan worden uitgeoefend om daadwerkelijke stappen af te dwingen. Er zou in dat verband kunnen 
worden gedacht aan concrete afspraken tussen landen die gaan samenwerken, elkaar de maat nemen, enzovoort. Dergelijke jumelages (bijv. van 4 of 5 landen uit steeds verschillende werelddelen) of twinnings (bijv. van een ontwikkeld en een ontwikkelingsland) moeten uiteraard niet op een willekeurige basis worden samengesteld, maar op grond van een gezamenlijk predominant probleem (bijv. water, delta's), belang (bijv. productie versus gebruik van hardhout) of gemeenschappelijk kenmerk (bijv. grote bevolkingsdruk). Onder die conditie hebben landen 'elkaar wat te vertellen' en is de kans op leereffecten het grootst.

\section{Thematische Medefinanciering als voorbeeld van bestuurlijke vernieuwing}

Een institutionele innovatie die recentelijk zijn beslag heeft gekregen met betrekking tot subsidieregelingen van het Ministerie van Buitenlandse Zaken aan NGO's is de zogeheten Thematische Medefinanciering (TMF; Staatscourant, 15 mei 2002). In het kader van TMF worden subsidieaanvragen niet langer louter en alleen beoordeeld in termen van de kwaliteit van individuele projectaanvragen. Veel meer wordt gekeken naar de reputatie en beheersstructuur (financiën, monitoring, kwaliteitscontrole, klachtenprocedures en evaluatiesysteem) van subsidievragende maatschappelijke organisaties. Het doel dat het ministerie voor ogen staat, is:

1. de ondersteuning van een goed ontwikkelde, onafhankelijke en professionele organisatie van de civil society (bij de uitvoering van activiteiten die structureel armoede willen bestrijden en daarbij biodiversiteit willen behouden);

2. het bevorderen en versterken van democratische maatschappelijke structuren en praktijken van goed bestuur; en

3. het stroomlijnen van subsidieregelingen als efficiency-operatie maar tevens ter bevordering van transparantie in de (politieke) verantwoording.

Het ministerie hoopt op den duur, samen met andere landen, een beleidsdialoog te ontwikkelen waarin ownership van problemen, en rollen en relaties tussen verschillende actoren transparant zijn. Net als bij OCM, is het ook hierbij van groot belang om indicatoren te ontwikkelen die betrouwbaar, toetsbaar en niet politiek manipuleerbaar zijn. Aan de verdere invulling en bijstelling van beleidsvoornemens wil men vorm geven in een dynamische relatie met organisaties in het Zuiden en het Noorden. Het einddoel is de ontwikkeling van innoverend vermogen met een toegevoegde waarde voor alle partijen door een beleidsdialoog te institutionaliseren. Hiertoe behoren de gesubsidieerde NGO's ieder voor zich te voorzien in een adequaat evaluatiesysteem voor effectieve feedback. Eens per vier jaar vindt een externe evaluatie plaats ten behoeve van het inzicht in de doelmatigheid, doeltreffendheid en het lerend vermogen van de betrokken stakeholders. Hierbij kan, net als in het kader van OCM, specifiek worden aangegeven hoe, vanuit de institutionele context van verschillende maatschappelijke organisaties, operationele doelstellingen zijn geformuleerd en strategieën zijn ontwikkeld. Door middel van externe rapportages moet tevens aangegeven worden hoe, en in welke mate, evaluaties in het verleden hebben geleid tot aanpassingen in de strategie en de dienstverlening aan beide zijden van de evenaar. De voorgestelde rapportages dienen te passen in het VBTB-beleid (van Beleidsbegroting tot Beleidsverantwoording) van de Nederlandse overheid.

De Thematische Medefinanciering is in bovenstaande box geillustreerd als voorbeeld van de wijze hoe, op basis van kwalitatief hoogstaande vormen van terugkoppeling, een beleidsdialoog kan worden ontwikkeld. Op basis van wederzijdse autonomie kan een effectieve beleidsdialoog de synergie tussen de activiteiten 
van de aanvrager (NGO) en de subsidieverlener (het ministerie) versterken. Specifiek gaat het er hierbij om beter gebruik te kunnen maken van de lokaal aanwezige kennisbronnen, een bijdrage te leveren aan de opbouw van lokale institutionele capaciteiten, en ten slotte de synergie en hefboomwerking te versterken voor wat betreft de coördinatie met andere projecten en programma's en de mogelijke bevordering van de herhaling van opgedane ervaringen met 'good practices'. 


\section{SAMENVATTING EN CONCLUSIE}

1. Dit rapport behandelt vraagstukken van bestuurlijke vernieuwing in verband met duurzame ontwikkeling. Hierover heeft de regering de raad om een advies gevraagd in een brief van 23 april 2002, naar aanleiding van de Nationale Strategie voor Duurzame Ontwikkeling. Verkenning van het Rijksoverheidsbeleid (2002). Bij bestuurlijke vernieuwing gaat het om bestuurlijke vraagstukken met betrekking tot:

- de samenwerking tussen overheid en maatschappelijke actoren;

- het nationale bestuur; en

- de internationale samenwerking.

2. In de Verkenning wordt het begrip 'duurzame ontwikkeling' in verschillende betekenissen gebruikt. Veelvuldig doelt het begrip op het streven het menselijk handelen in balans te brengen met het ecologisch draagvlak. Naast deze waarde wordt duurzame ontwikkeling echter ook in een veel bredere betekenis gebruikt, in dit rapport aangeduid als het metabegrip 'duurzame ontwikkeling', waarbij duurzaamheid betrekking heeft op zowel de ecologische, economische en sociaal-culturele kwaliteit.

3. De raad meent dat er voor de bestuurlijke vormgeving van het beleid moet worden uitgegaan van het begrip 'duurzame ontwikkeling' als waarde. Dat houdt in dat het moet worden afgebakend tot het ecologische aspect en de afwegingen die van daaruit moeten worden gemaakt met de economische en sociaal-culturele waarden. Vanuit deze beleidsdoelstelling moeten afwegingen met andere doeleinden worden gemaakt en moeten prioriteiten worden gesteld.

De raad acht het ongewenst om het ruimere metabegrip in het bestuurlijke proces te hanteren. Duurzame ontwikkeling krijgt hierdoor een zodanig integraal en allesomvattend karakter dat het begrip niet de basis kan vormen voor te maken beleidskeuzes. Dit doet natuurlijk niet af aan het feit dat op vele gebieden een 'generatiebewust' beleid noodzakelijk is; denk bijvoorbeeld aan het pensioenbeleid, het onderwijsbeleid of de gezondheidszorg. Dat beleid heeft echter zijn eigen merites. Het voegt weinig toe om het onder een alomvattende doelstelling van 'duurzame ontwikkeling' te brengen.

4. De regering lijkt in haar Verkenning wél voor een brede opvatting van duurzame ontwikkeling te hebben gekozen. Meer uitgewerkt kunnen de bezwaren hiertegen als volgt worden samengevat:

a Het onder deze algemene doelstelling brengen van het beleid op welhaast ieder gebied veronderstelt een vorm van integrale beleidsvoering die onmogelijk is. Het beleid kan alleen vorm krijgen vanuit meer specifieke en duidelijker afgebakende doelstellingen.

b Beleid moet het resultaat zijn van prioriteitstelling en afweging van doelstellingen tegen elkaar. Door een algemene doelstelling te formuleren 
wordt het zicht verhinderd op de keuzes die gemaakt moeten worden, en worden hiermee de noodzakelijke politieke afwegingen belemmerd.

5. In verband met dit laatste punt vraagt de raad verder aandacht voor de verhouding tussen wetenschap en politiek. Hoewel wetenschappelijke kennis van grote betekenis is voor het beleid ten aanzien van duurzame ontwikkeling, biedt de wetenschap in veel gevallen niet de zekerheden die beleidsmakers zouden wensen. Bovendien kan de wetenschap nooit de afwegingen voorschrijven die gemaakt moeten worden; bijna altijd zijn er tegenstrijdige beleidsdoelstellingen die om voorrang strijden. Politiek en beleid zullen - met de beste wetenschappelijke kennis die beschikbaar is - zelf de afwegingen moeten maken, liefst zo transparant mogelijk en in het licht van alternatieven. De raad pleit er daarom voor om in de nationale strategie duidelijke politieke keuzes te maken op grond van een expliciete afweging tussen de alternatieve mogelijkheden. Anders dan nu in de Verkenning, komen dan de dilemma's in beeld en ontstaat zicht op de redeneringen die worden gehanteerd en de risico's die aanvaardbaar worden gevonden.

Om inzicht te krijgen in de beleidsalternatieven is het noodzakelijk dat de beleidsvoorbereidende kennisinstellingen per onderwerp gericht samenwerken.

6. Bestuurlijke vernieuwing is gewenst en is ook gaande. In veel gevallen is het beleid al responsiever en interactiever geworden. Deze richting dient verder te worden versterkt, en niet - alsnog - in een top-down-kader geplaatst te worden. Deze opvatting van de raad staat in contrast met de alomvattende bestuurlijke ambities die uit de Verkenning spreken. Deze overschatten de cognitieve en sturingsmogelijkheden van de overheid. De positie van de overheid in de samenleving is bovendien veranderd en de burger is mondiger geworden. Hierdoor is interactie van de overheid met burgers, bedrijven en organisaties van groter belang geworden en moet er meer ruimte worden gegeven aan de eigen verantwoordelijkheid van andere actoren in de samenleving, evenals voor hun mogelijke bijdragen aan creatieve oplossingen van maatschappelijke problemen.

De raad meent dat in veel gevallen een vereenvoudiging en ontvlechting van het beleid eerder aangewezen is dan een verdere beleidsstapeling. Dat biedt ook de meeste ruimte voor terugkoppelingen en leerprocessen in het beleid.

7. In het licht van bovenstaande punten sluit dit rapport af met een aantal suggesties voor verdere bestuurlijke vernieuwing op de drie in de adviesaanvraag genoemde terreinen: samenwerking met actoren in de samenleving, bevordering van samenhang op nationaal niveau en internationale samenwerking. Gezien de zeer korte termijn waarop dit advies is gevraagd, hebben de beschouwingen hierover een richtinggevend karakter zonder dat ze op alle punten al volledig zijn uitgekristalliseerd. 
8. Wat de samenwerking met actoren in de samenleving betreft, is het bevorderen van duurzame ontwikkeling minder een exclusieve overheidsverantwoordelijkheid geworden. Er moet ruimte worden gegeven aan de eigen verantwoordelijkheid van private actoren. Een strakke overheidssturing met gedetailleerde normen en strakke handhaving is lang niet altijd realistisch en loopt het risico de private verantwoordelijkheid te verengen tot het volgen van de regels. Hier spelen onder andere convenanten, benchmarking en open vormen van coördinatie op nationaal niveau een rol, waarbij het beleid zich 'lerend' en 'experimenterend' kan ontwikkelen door zo goed mogelijk 'lokale' kennis te gebruiken. Verder is het is van belang de samenwerking met organisaties die zich inzetten voor duurzame ontwikkeling enigermate te institutionaliseren. Deze institutionalisering dient evenwel een 'licht' karakter te behouden, zoals dit de laatste jaren bijvoorbeeld in de SER is vormgegeven door milieuorganisaties in een tweetal relevante commissies op te nemen.

Verder is het is van belang indicatoren te ontwikkelen, maar deze moeten zorgvuldig worden gekozen en een directe relatie hebben met de gevoelde ecologische problemen en de te maken afwegingen. Een indicator als Duurzaam Nationaal Inkomen heeft slechts beperkte waarde.

9. Bij de bevordering van de samenhang op nationaal niveau is een expliciete afweging tussen de verschillende doelstellingen van beleid van groot belang. Evenals een alomvattende beleidsdoelstelling 'duurzame ontwikkeling' ongewenst is, moet niet één minister - ook niet de minister-president - de coördinerende verantwoordelijkheid voor een dergelijke brede doelstelling toebedeeld krijgen.

10. Met betrekking tot de internationale samenwerking dienen vormen van open coördinatie - gericht op commitment en leergedrag - gecombineerd te worden met bestuurlijke mechanismen om vorderingen te kunnen vaststellen. Daarbij kan het helpen als landen in kleinere groepen (dan het totaal van 18o) gaan samenwerken op basis van een gemeenschappelijke noemer. 


\section{LITERATUUR}

Adriaanse, A. (1993) Environmental policy performance indicators. A study on the development of indicators for environmental policy in the Netherlands, Den Haag: Sdu Uitgeverij.

Algemene Rekenkamer (2001) Invoering mineralenaangiftesysteem (MINAS), Tweede Kamer, vergaderjaar 2000-2001, 27 825, nrs. 1-2, 26 juni 2001.

Algemene Rekenkamer (2002) Bestrijding uitstoot broeikasgassen, Tweede Kamer, vergaderjaar 2001-2002, 28 272, nrs. 1-2, 21 maart 2002.

Atkinson, T., B. Cantillon, E. Marlier and B. Nolan (2002) Social indicators. The EU and social inclusion, Oxford: Oxford University Press.

Butter, F.A.G. den, M.W. Hofkes en H. Verbruggen (1994) 'Hoe meten we duurzaamheid?’, ESB, jrg. 79: 638-642.

Gibson, D. and R.E. Goodin (1999) 'The veil of vagueness: a model of institutional design', blz. 301-329 in M. Egeberg and P. Laegreid (eds.) Organizing political institutions. Essays for Johan P. Olsen, Oslo: Scandinavian University Press.

Hazeu, C.A. (200o) Institutionele economie. Een optiek op organisatie- en sturingsvraagstukken, Bussum: Coutinho.

Hazeu, C.A. (200oa) 'Sturingsmogelijkheden in het milieubeleid; een institutioneeleconomisch perspectief’, Milieu, jrg. 15, no. 5: 241-253.

Intergovernmental Panel on Climate Change (2001) Summary for policymakers. A report of working group I of the Intergovernmental Panel on Climate Change, en Summary for policymakers. Climate change 20o1: Impacts, adaptation, and vulnerability, Genève.

Lindblom, Ch. E. (1965) The intelligence of democracy. Decision making through mutual adjustment, New York: Free Press.

Maas, R.J.M. (200o) Hoezo duurzaam? Een bijdrage aan het debat over duurzame ontwikkeling, Bilthoven: RIVM.

March, J.G. (1999) The pursuit of organizational intelligence, Oxford: Blackwell.

Ministerie van Volkshuisvesting, Ruimtelijke Ordening en Milieubeheer (2002) Nationale strategie voor duurzame ontwikkeling. Verkenning van het Rijksoverheidsbeleid, Den Haag.

Peppel, R. van de, en J. Woltjer (2002) 'Een verklaring voor de trage uitvoering van convenanten: de uitvoering van het convenant Glastuinbouw en Milieu', Beleidwetenschap, jrg. 16, no. 1: 32-50.

Pearce, D. and G. Atkinson (1995) Measuring sustainable development, blz. 166-181 in D.W. Bromley (eds.) The handbook of environmental economics, Oxford: Blackwell.

Sabel, Ch.F. (1994) 'Learning by monitoring. The institutions of economic development', blz. 231-274 in L. Rodwin and D.A. Schön (eds.) Rethinking the development experience. Essays provoked by the work of Albert O. Hirschman, Washington D.C: The Brookings Institution.

Scheltema, M. (2002) Publieke en private verantwoordelijkheid in een kennissamenleving, rede Congres voor Milieurecht: Amsterdam; zie ook http://www.wrr.nl. 
Sociaal-Economische Raad (2001) Werken aan draagvlak. Evaluatie van de adviestaak van de Sociaal-Economische Raad, Den Haag.

Sociaal-Economische Raad (2002) Advies over de nationale strategie voor duurzame ontwikkeling, 17 mei 2002, Den Haag.

Verbruggen, H. ( ed.) (200o) Final report on calculations of a sustainable national income according to Hueting's methodology, Amsterdam: Vrije Universiteit/Institute for Environmental Studies.

Visser, J. en A.C. Hemerijck (1997) 'A Dutch miracle': job growth, welfare reform and corporatism in the Netherlands, Amsterdam: Amsterdam University Press.

Visser, J. en A.C. Hemerijck (2001) Learning ahead of failure: a research agenda, paper presented at the Max Planck Institute: Keulen.

Wetenschappelijke Raad voor het Regeringsbeleid (1994) Duurzame risico's. Een blijvend gegeven, Rapporten aan de Regering nr. 44, Den Haag: Sdu Uitgevers.

Wetenschappelijke Raad voor het Regeringsbeleid (1999) Generatiebewust beleid, Rapporten aan de Regering nr. 55, Den Haag: Sdu Uitgevers.

Wetenschappelijke Raad voor het Regeringsbeleid (200o) Doorgroei van arbeidsparticipatie, Rapporten aan de Regering nr. 57, Den Haag: Sdu Uitgevers.

Wetenschappelijke Raad voor het Regeringsbeleid (2001) Ontwikkelingsbeleid en goed bestuur, Rapporten aan de Regering nr. 58, Den Haag: Sdu Uitgevers.

Wetenschappelijke Raad voor het Regeringsbeleid (2001) Nederland als immigratiesamenleving, Rapporten aan de Regering nr. 6o, Den Haag: Sdu Uitgevers.

Wetenschappelijke Raad voor het Regeringsbeleid (2002) Van oude en nieuwe kennis. De gevolgen van ICT voor het kennisbeleid, Rapporten aan de Regering nr. 61, Den Haag: Sdu Uitgevers.

World Commission on Environment and Development (1987) Our common future, Oxford/New York: Oxford University Press. 